\title{
MODERNIDAD, SOCIEDAD Y CONSTITUCIONALISMO EN AMÉRICA LATINA*
}

\author{
Raúl ZAMORANO FARÍAS**
}

RESUMEN: El objetivo de este trabajo es reflexionar sobre la problemática relación entre el sistema democrático y las particulares formas de constitucionalización de la Constitución en América Latina, observando la creciente y compleja relación evolutiva entre las expectativas normativas y las formas de sociabilidad en el proceso de creación jurídico-político de la sociedad, así como las dificultades de las formas institucionales para lograr acomodos políticos que ayuden a la estabilización de las complejas democracias en la región.

Palabras clave: modernidad, sociedad, democracia, constitucionalismo, Estado, ciudadanía.
ABSTRACT: The objective of this work is to reflect on the problematic relation between the democratic system and the particular forms of constitucionalización of the Constitution in Latin America, observing the flood and complex evolutionary relation between the normative expectations and the forms of sociability in the legal-political process of creation of the society, as well as the difficulties of the institutional forms to obtain political arrangements that help to the stabilization of the complex democracies in the region.

Descriptors: modernity, society, democracy, constitucionalism, State, citizenship.

* Este trabajo se inscribe en el programa de investigación que desarrolla el autor y formó parte del proyecto de investigación: "Democracia y formas de inclusión-exclusión política en el sistema político mexicano 2000-2005", clave UAEM 2369/2006-02.

** Profesor-investigador de la Universidad Autónoma del Estado de Mèxico. Professore e membro nel Collegio dei Docenti (Dipartimento di Studi Giuridicci - UNILE). Miembro del SNI.

Fecha de recepción: 6 de noviembre de 2007.

Fecha de dictamen: 17 de abril de 2008 . 


\section{INTRODUCCIÓN}

En América Latina, ha sido característico que los estudios sobre los procesos de cambio sociopolítico y económico concluyan que las sociedades periféricas, como las latinoamericanas, deben llegar a ser desarrolladas. En otras palabras, las autodescripciones y las teorías que se han elaborado para dar cuenta de esta problemática, avalan una presunta teleología de orden y progreso que nos debe sacar del subdesarrollo a partir de un Estado fuerte e interventor, el cual lleve las riendas hacia el pleno desarrollo, siguiendo la imagen de las sociedades centrales. ${ }^{1}$

Nuestra investigación toma en cuenta ciertamente estos aspectos, pero pensamos que es necesario concentrarse también en las dimensiones político-jurídicas implícitas en tales procesos; que obviamente no son menos problemáticas. Evidenciar, por ejemplo, la discrepancia siempre más fuerte entre la semántica político-jurídica de la modernidad y la materialidad de las relaciones sociales existentes, en las cuales conceptos como emancipación, racionalidad, modernización, sociedad mundial (junto a la confianza en los valores que la sociedad actual ha asumido como propios desde su inicio y que han sido sedimentados en las Constituciones y los programas políticos), no hacen otra cosa que hacer más vistosa y preocupante esta problemática.

1 Al respecto, piénsese en la teoría económica propuesta por la CEPAL a mediados y fines del siglo XX, o en la teoría de la modernización elaborada por Gino Germani y Walt Rostov; el enfoque de la teoría de la dependencia de Fernando Cardoso y Enzo Faletto; la teoría de la marginalidad propuesta por el jesuita Roger Vekemans en DESAL; la opción neoliberal cristalizada en los postulados utilitaristas y pragmáticos de Milton Friedmann y la Escuela de Chicago. Todas estas elaboraciones y autodescripciones tienen como base una particular distinción entre centro/periferia, cuya concepción es que las sociedades atrasadas, como las latinoamericanas, deberían llegar a ser desarrolladas. La lógica que subyace a dichas teorías se orienta en función de alcanzar un orden y progreso para salir del subdesarrollo a partir de un Estado fuerte e interventor que lleva las riendas hacia el pleno desarrollo. Es decir, a imagen y semejanza de las modernidades centrales. He desarrollado y problematizado exhaustivamente estas concepciones en $\mathrm{Ci}$ vilizzazione della aspettative e democrazia nella periferia della società moderna, Lecce, Pensa Multimedia, 2004. Específicamente en "Formas históricas de coordinación social en América Latina: de la teoría de la dependencia al fetichismo neoliberal”, Rivista Teoria del Diritto e dello Statto, Roma, Aragne Editore, 2007. 
Nos proponemos entonces articular una propuesta de observación y problematización de estos procesos, apelando al instrumental teórico ofrecido por la teoría de los sistemas sociales en su aplicación a la especificidad de los sistemas sociales en la periferia de la sociedad moderna, cuya característica parece estar signada por la dificultad de coordinación entre política, derecho y estructuración de las expectativas. El objetivo general se orienta a la observación de cómo funcionan, en el contexto de la sociedad moderna, los sistemas democráticos de la periferia; es decir, no nos interesa, expresamente, saber qué cosa sea la democracia sino observar cómo ésta viene operando en el marco de una complejidad filtrada por la variedad y discontinuidad semántica de los lenguajes, del conocimiento, de las técnicas, de las expectativas y de los valores normativos que son practicados en su interior, y de sus ulteriores diferenciaciones en el contexto de la modernidad de la sociedad moderna.

\section{EL ETHOS DE LA MODERNIDAD Y SUS PRESUPUESTOS}

\section{Adversus modernità}

La referencia a la modernidad, aquella percepción, autodescripción y posición frente al mundo que caracteriza el ideario moderno, es una transformación compleja que puede ser abordada desde diferentes disciplinas y enfoques teóricos. Conscientes de enfrentar los riesgos que comporta toda generalización, podemos decir que la modernidad se enmarca en la forma y el surgimiento, tanto en el plano práctico como en el plano cognitivo, de una nueva subjetividad que responde a aquella concepción del racionalismo ilustrado, donde el hombre es el sujeto por excelencia del conocimiento y de la acción: el hombre autónomo (auto-nomos = ley) capaz de gobernarse a sí mismo (N. Elias llama a esto el proceso de civilización). Es sobre estas bases en que está centrado todo el pensamiento de la modernidad, lo cual, ni duda cabe, ha tenido implicancias sustantivas en la evolución del pensamiento contemporáneo, así como en las periferias.

Recordemos que desde sus orígenes la articulación del ideario de la sociedad moderna quedó sometido a la lógica dominadora de la razón, de la ciencia y del poder como se evidencia ya en la constitución de las gigantescas burocracias modernas - descritas por M. Weber a comienzos 
de siglo-, y en el derecho positivo de los Estados (G. Jellenik, H. Kelsen). La ciencia moderna surgió como resistencia a la autoridad de la fe que había dominado el horizonte del saber durante el largo trance medieval. De igual manera la ética moderna se afirma como ética de la autonomía, distanciándose de las concepciones cosmológicas e teocéntricas, tan características del medioevo. ${ }^{2}$

Ya en la concepción sobre el mundo que propone Giordano Bruno - como universo infinito de mundos - estaba contenida potencialmente la acepción moderna de la materia y del valor. Esta afirmación generó dos consecuencias que serían fundamentales para la edificación de la estructura conceptual moderna. Por un lado, el mundo pierde su cualidad de finitud y se torna infinito (contingente se podría decir). Del otro, el lugar del valor es dislocado desde el macrocosmos hacia el microcosmos; allí cada mónada existente posee en sí la pulsión individual del ser (visión homocéntrica), tal que para el horizonte moderno la razón y la experiencia serán las principales, y con posterioridad, las únicas fuentes de verdad. ${ }^{3}$

Por lo tanto, la modernidad ilustrada viene a representar un proyecto, una semántica emancipatoria que se estructura sobre la base del sujeto racional (que deviene ciudadano), el cual fue imponiendo frente a la naturaleza y la sociedad su potencialidad creadora y transformadora, dominando su entorno mediante prácticas basadas en el conocimiento científi-

2 Con Spinoza, la ontología de la esencia deviene en potencial factual. El Uno es en tanto potencia de efectuar/afectar escribe Spinoza. Véase Deleuze, Gilles, En medio de Spinoza, Buenos Aires, Cactus, 2005.

3 Precisamente, este desplazamiento será realizado en función del afán racionalizador de la modernidad. Modernidad que a juicio de sus críticos desembocara en el siglo $\mathrm{XX}$ en el totalitarismo fascista y estalinista, lo que en consecuencia termina por convertirse en una nueva forma de sometimiento del propio sujeto que es su soporte, toda vez que la razón totalizante va destruyendo los mitos y tradiciones culturales, así como también otros planos de la realidad lo cual reduce, en última instancia el sentido mismo de la existencia. Quizás por ello la crítica deconstructivista de los teóricos poscoloniales - Said, Bhabha, Spivak - no viene motivada por la creencia en un ámbito moral de exterioridad frente a la modernidad occidental y mucho menos por una idea del retorno nostálgico a formas tradicionales de existencias. "Ellos saben perfectamente que la occidentalización es un fenómeno planetario sin retorno y que lo único viable para todo el mundo es aprender a negociar con ella", Castro-Gómez, Santiago y Mendieta, Eduardo, Teorías sin disciplina. Latinoamericanismo, poscolonialismo y globalización en debate, México, Porrúa-USF, 1998, p. 17. 
co. Esta autonomía del sujeto, avalada por la ciencia empírico-racional, apunta a una superación y a una negación del dogma y de las tradiciones que oprimen la autonomía individual. No obstante la historicidad de esta evidencia, constituye el topos desde donde precisamente emergieron y emergen las críticas, los reclamos y las utopías de subversión para reformar y modificar el proyecto moderno, pues se piensa que en su núcleo mismo está contenida la valoración de la autonomía individual. ${ }^{4}$

Las críticas a la modernidad (el desplazamiento del mito religioso a la razón) son de vieja data y se han orientado, persistentemente, en torno al concepto de totalidad, centrando principalmente los ataques contra Hegel y su filosofía. ${ }^{5}$ Este enjuiciamiento ha sido acompañado por el rechazo total a la tesis sobre la existencia de un logos unificador del todo. Es decir, de la razón y de un determinante último (esencia) que explicaría lo diverso. En general, según los críticos de la modernidad, la tendencia totalizante, que es tan propia del pensamiento teórico moderno, contiene desde siempre todos los elementos del totalitarismo práctico. Incluso Lyotard nos habla del terrorismo de la teoría y sostiene que los siglos

4 Que sin embargo y pese a sus innegables logros no se plasmó, recreándose en nuevas formas de sujeción y control, frente a las que el sujeto reaccionara.

5 Muy tempranamente, desde las entrañas de la propia modernidad, se incuban y emergen fuertes críticas contra sus efectos. Críticas que no vienen a renegar de la modernidad como tal, sino que más bien se postulan como alternativas al interior o en las fronteras de ésta. Ese es el papel, por ejemplo, de una vertiente del romanticismo alemán que veía la modernización del mundo como la escisión ontológica entre la naturaleza mecanizada, desacralizada y el hombre. Ese será también el papel de la crítica de la economía política. Para Marx la crítica de la modernidad se concentró originariamente en la problemática de la alienación, es decir, en la temática de la falta de control del hombre sobre sus productos y en su sometimiento al fetichismo de la mercancía, ligado evidentemente a la lógica de la producción capitalista. Desde otro ángulo, pensadores como Nietzsche cuestionaron el proyecto masificante y nivelador de la modernidad y su correlativo racionalismo. La crítica del irracionalismo se opone a la voluntad del poder; opone lo instintivo a la razón. No obstante y paradójicamente continúa al servicio de la razón, puesto que ni Marx ni Nietzsche, toda vez que se oponen a la realidad inmediata, siguen proyectando una realidad del mañana en términos racionales. Más adelante, las críticas en torno al problema de la soledad del hombre y de la tragedia de la condición humana, se constituyen el punto de partida de lo que será el existencialismo. Sartre intenta de alguna manera responder al vacío de la vida, a la nausea de una modernidad que viene socavando los mitos que dan sentido a la vida del hombre. A pesar de éstas y otras críticas embestidas, el proyecto moderno, racional-cientificista y de culto al progreso, continuó su ascenso alcanzando el apogeo con el positivismo. 
XIX y XX nos han proporcionado terror hasta el hartazgo, con lo cual ya habríamos pagado suficientemente la nostalgia del todo y del uno, de la reconciliación del concepto y de lo sensible, de la experiencia transparente y comunicable. ${ }^{6}$

En el último tiempo las críticas a la modernidad están relacionadas con el vaciamiento o la pérdida del sentido de la existencia, especialmente cuando al develar y de(con)struir el mundo encantado del mito y de la creencia religiosa la modernidad ha propuesto fines terrenales que siempre se postergan y reformulan hacia el futuro (las promesas no cumplidas, horizontes expectantes de sentido) tal que, y a fin de cuentas, se vuelven quimeras inalcanzables, las cuales terminan irreductiblemente escapándose, dejando al sujeto instalado en un callejón sin salida o, como es hoy moneda corriente afirmar, en el nihilismo como "final" de la modernidad y de la historia.

Empero, el programa racionalista ilustrado, junto con instituir la liberación del sujeto, generó también una nueva concepción de sociedad, cuya característica central ya no sería el predominio de lo prescriptivo (jusnaturalismo), ${ }^{7}$ sino el carácter contractual como cemento y orden de lo social democrático (contractus-norma). ${ }^{8}$ De allí que aquella concepción sobre la razón universal, por sí sola, así como la presunción de que el soberano es, necesariamente, bueno y temeroso de Dios, será progresivamente sustituida en los siglos XVII-XVIII por la noción de "derechos", como limitadores de la soberanía (concebida, desde sus primeras formulaciones en el siglo XVI, también como un "derecho"). Para Kant, por ejemplo, esta tensión entre soberanía y derechos se desplaza a través del sacrificio de la soberanía popular, en función de la necesidad de una Constitución republicana, donde representación, prohibición de la resis-

6 Véase Lyotard, Jean F., La condición postmoderna, Madrid, Ediciones Cátedra, 1989 y "Qué era la postmodernidad", en Casullo, Nicolás, El debate modernidad. La modernidad, Buenos Aires, Punto Sur, 1989, passim.

7 El problema central que se plantean los pensadores de la época (Hobbes, Spinoza, Kant, Locke, Voltaire), gira en torno a cómo organizar una sociedad en su evolución del status al contractus. Desde Hobbes en adelante, el contractualismo se constituyó en la explicación del fundamentó del orden político y social.

8 Paradójicamente, resulta notable que en la actualidad el carácter fundamental de la identidad está dado por el principio de la adscripción y no de la adquisición, a contra-corriente de toda la tradición sociológica y politológica Sobre este crucial aspecto véase el interesante trabajo de Mires, Fernando, Ciencia nueva (título provisorio del manuscrito), Alemania, Odenburg, 2002 (especialmente primera parte). 
tencia y del derecho a la desobediencia a los derechos, son mecanismos que limitan la supremacía de la soberanía popular cuando se hace necesario (derecho de resistencia, Tomasso d'Aquino).

En adelante, podemos observar cómo el ideario ilustrado de la modernidad ha estado permanentemente reformulándose, en función de un proyecto de racionalización del universo mediante su explicación y comprensión, pero además mediante su transformación. De ahí también que la razón esté ligada a la acción técnica, tanto en la naturaleza como en la sociedad. Así, gradualmente la historia deja de ser una serie de acontecimientos que ejecutan un plan cósmico, o divino, para convertirse en un curso que conduce a fines trazados por el hombre mismo, en un sentido que trasciende al individuo y que tiende a su emancipación de las trabas sempiternas (opresión, escasez, injusticia). Sobre estos presupuestos la democracia moderna sentará sus bases.

Precisamente, el desarrollo del sistema democrático busca articular una instancia política separada de los poderes religiosos y económicos, para configurar un aparato administrativo centralizado y operativo en donde se concentren los medios de violencia legítima (soberanía) y la constitucionalización, o sujeción a un derecho positivo (legalidad), lo cual implica una división de poderes contrabalanceados y la autonomía funcional. Es decir, la sujeción de los poderes estatales al mandato del sufragio universal (legitimidad), dando origen al moderno Estado constitucional, cuya concepción democrática presupone un Estado de derecho que garantice el orden jurídico y que mantenga a sus autoridades sujetas al escrutinio público.

En última instancia, el resultado de todo esto es el desencantamiento y la transformación del poder, tras la desdramatización de la política; es decir, tras la reducción de sus aspectos expresivos y un aumento de las capacidades simbólicas e instrumentales en la gestión; pues, precisamente, será con la pérdida del aura ideológica en favor de los intereses prácticos de los actores que se encuentran y desencuentran en el mercado político, siguiendo la gramática schumpeteriana, lo que, a fin de cuentas, posibilite una mayor autonomía de la política y del derecho vía diferenciación y especialización funcional y operativa. ${ }^{9}$

9 Schumpeter, Josep, Capitalismo, socialismo e democrazia, Milán, Etas Libri, 1977, véase también Brunner, José J., Un espejo trizado, Santiago, FLACSO, 1988, p. 9. 
En este largo proceso evolutivo de superación del pensamiento antiguo y medieval, el reconocimiento de la complejidad siempre creciente fue dando por resultado modernas configuraciones de la ciencia, de la ética, de los sistemas del derecho (que, como señala Hegel, surge para domesticar a la bestia del mercado y delinear el Estado, resolviendo la contraposición entre iusnaturalismo y iuspositivismo con la creciente positivación de nuevos contenidos), de la política (en las diversas formas que asume el Estado y su relación con la ciudadanía) y de la economía (con sus variados medios de producción y distribución de riquezas y de la organización del trabajo), que fueron desenvolviéndose y especializándose a partir de estructuras internas propias de operación, observación y reproducción (códigos).

Fundada sobre una ciencia empírica deductiva, que posibilitó la formulación de generalidades - leyes - , el ideario de la modernidad se pensó a sí mismo como un proyecto de civilización tecnológica, que confiando en el conocimiento científico buscó la solución a los problemas de la humanidad y de su felicidad. De allí que la síntesis de la cultura moderna fuese aquella optimista concepción de la historia que se afirmaba como progreso indefinido, lleno de sentido ascendente. Para el mito de la razón la trayectoria de la utopía moderna consistía en el despliegue que iba desde la barbarie hasta al liberalismo democrático, punto de llegada definitivo al interior del cual se desenvolverá todo el acontecer sucesivo. Pero en las postrimerías del siglo XX, esta forma de conceptualizar la modernidad entra en crisis y se reconoce como fallida, generándose al interior del corpus teórico una aguda crítica que sin embargo fracasa por su incapacidad para dar sentido a la acción en una sociedad cada vez más compleja y diferenciada (toda vez que continúa anclada en concepciones de desarrollo lineal y acoplamiento armonioso de la sociedad). Dicho en palabras del propagandista Fukuyama, es el otro fin de la historia. ${ }^{10}$

A la crisis de la modernidad se suma la crisis de la democracia, de los derechos, de las garantías individuales y de la esfera estatal que lógicamente viene ligada a la crisis de la política moderna, ya que mientras el Estado ha perdido el monopolio de la política, esto es, la idea clásica donde lo político era todo lo que concernía al Estado, la política ha perdido también su rol como centro activo y orgánico de la sociedad. Sin

10 Recordemos que para W. F. Hegel la reformada monarquía prusiana representa en sí, el fin de la evolución de la humanidad, es decir, el fin de la historia. 
embargo, y a pesar de tan dramáticas constataciones, una parte importante del ideario político continua orientado de acuerdo al registro contenido en antiguos contratos sociales sin preguntarse en qué medida la idea misma de contrato social, en el marco de una creciente descentralización de la acción política, puede aún ser vigente. ${ }^{11}$

Es en este contexto donde la cuestión relativa a los derechos ciudadanos y las garantías individuales emerge con fuerza, como un recurso para contener el desmantelamiento del Estado y proteger a los individuos contra los abusos del autoritarismo y el cierre de la inclusión social. Por cierto, esta particularidad conferida a los derechos, así como vienen utilizados hoy, es claramente el sedimento de un proceso histórico y evolutivo de la sociedad y del mismo sistema del derecho (N. Luhmann). Por ello también la importancia de mantener constante la referencia con el proceso de civilización en la modernidad, porque es sólo con la modernidad que se hace necesario codificar los derechos.

En el proceso evolutivo de la sociedad moderna los temas del derecho, la política y la economía estuvieron intrínsecamente muy ligados, y esto puede ser observado a partir de la problematización de los derechos fundamentales, de sus transformaciones en el plano constitucional y sus consecuencias para una praxis de la ciudadanía y consolidación de la democracia. Sabido es que en el pensamiento jurídico, y en la teoría política clásica, existen dos tradiciones que afirman diferentes formas de explicar la fundación y, por tanto, también el fundamento del orden político y jurídico de la sociedad (republicanismo-liberalismo). Estas tradiciones son descritas frecuentemente como antagónicas y sostienen, de un lado, el principio de la soberanía popular y, del otro, la primacía de los llamados derechos individuales ("humanos"). Las principales confrontaciones y divergencias teóricas giran, en lo fundamental, en torna a la forma del cómo se articulan en la modernidad las nociones de soberanía y de ciudadanía para hacer posibles decisiones políticas jurídicamente fundadas, que se justifican con base en los derechos individuales, o bien como de-

11 Se debe considerar además que la distinción clásica, empleada en el ámbito de la sociología política, entre política/sociedad, que remite filosóficamente a la distinción entre espacio público de la vida política y la economía doméstica, y cuyo componente ético se afirma en una supuesta naturaleza humana, orientada hacia su perfección en la comunidad política (vida buena), es también inadecuada. En la actualidad, incluso sociológicamente, el concepto filosófico de la koinonía politiké (como su moderna acepción: "sociedad civil”) deviene analíticamnte estéril. 
cisiones jurídicas políticamente tomadas sobre la base del principio de la soberanía popular (derechos fundamentales).

En términos generales los derechos, institucionalizados en forma escrita y codificada hacia finales del siglo XVII, fueron propuestos como derechos subjetivos, en el sentido que se pretendía encontrar en el sujeto su fundamento y la posibilidad de ser revindicados y eventualmente impuestos. ${ }^{12} \mathrm{Al}$ respecto, un hito importante lo constituye la declaración, tras la Glorious Revolution de 1688, de ciertos derechos fundamentales, sobre todo el Habeas Corpus (1679) y la Bill of Rights (1689), consagrando, de hecho, la igualdad humana frente a la ley y en cuyo centro se encontraba la garantía del parlamento como representante del pueblo y de la propiedad privada (J. Locke).

Pero tal subjetividad - derecho subjetivo- pudo ser generalizada e institucionalizada sólo al precio de eliminar al sujeto mismo la posibilidad de elección, toda vez que no puede encargarse de las innumerables variantes que la realidad subjetiva e individual muestra. Así, los derechos subjetivos operarán como una expectativa posible de ser garantizada a través de la institucionalización por el derecho positivo. L. Ferrajoli señala que las garantías de los derechos (primarios o secundarios) son el conjunto de las obligaciones implicadas por tales derechos, normas previstas y por otras normas positivas (imputables). ${ }^{13}$

12 De hecho, como sostiene Hinkelammert, para muchos fines la historia de los derechos humanos modernos es a la vez la historia de su inversión, la cual transforma la violación de estos mismos derechos humanos en un imperativo categórico de la acción política. La conquista española de América se basó en la denuncia de los sacrificios humanos que cometían las civilizaciones aborígenes americanas. Más tarde, la conquista de América del Norte se argumentó por las violaciones de los derechos humanos por parte de los aborígenes. La conquista de África por la denuncia de canibalismo, la conquista de India por la denuncia de la quema de las viudas, y la destrucción de China por las guerras del opio se basó igualmente en la denuncia de la violación de derechos humanos en China. El occidente conquistó el mundo, destruyó culturas y civilizaciones, cometió genocidios nunca vistos; sin embargo, todo eso lo hizo para salvar los derechos humanos (en nuestros días y usando nuevamente el argumento de la defensa de los derechos humanos, el parapléjico mental que regenta la Casa Blanca justifica nuevas masacres).

13 Derechos fundamentales son lo que dan fundamento a una forma particular de convivencia (expectativa cognitiva) que al constitucionalizarse se hace norma (expectativa normativa), generando las condiciones fundamentales de legitimidad (poder) del derecho público (el fundamento sería una expectativa civilizada). Definidos como anteriores a los deberes, como afirman — entre otros — Spinoza y Bobbio; prima el derecho sobre el 
Precisamente, la preocupación del contractualismo moderno centra su atención en la protección de los derechos fundamentales, de las garantías (forma positiva, objetiva: obligaciones y deberes primarios y secundarios) y de la tutela y autotutela del poder (J. Locke). Entonces, bajo esta premisa, lo que queda claramente establecido es que el derecho sin posibilidad de garantía positiva es sólo una pretensión moral. ${ }^{14}$

A partir de ahí las tres formas clásicas para la defensa de los derechos fundamentales se articulan, en lo fundamental, sobre la base de la propuesta kantiana: a) Constitución cosmopolita, ${ }^{15}$ a través del establecimiento de programas condicionales, b) sistema supraestatal de garantías que podría consistir en una limitación y regulación de los deberes y obligaciones de los Estados en relación con los sujetos imputables de derechos (ciudadanos), y c) tutela, vía intervención coactiva en función de la defensa de los sujetos afectados en sus derechos (policía mundial). En esta fórmula, los derechos subjetivos son derechos sí, y sólo sí, se hacen en sí mismos objetivos (derecho positivo). ${ }^{16}$

Llegados a este punto creemos necesario señalar algunas aclaraciones conceptuales y de método pues, como advertía Hegel, no existe modo más fácil de eludirse a sí mismo y a los otros que el presuponer el conocimiento de algo ya conocido para dejarlo tal como está.

deber, característica del contractualismo moderno, mientras que en el contractualismo clásico prima el deber sobre el derecho.

14 Recordemos que el derecho natural no es un derecho positivo (no tiene garantías). Además, ni siquiera queda espacio, en última instancia, para el uso legal del poder de resistencia, como plantea Santo Tomás. Entendiendo la resistencia como una forma extrema de defensa de los titulares cuando son violados sus derechos por el soberano (Estado); pero el derecho de resistencia puede verificarse cuando hay ruptura del pacto (contrato) por parte del mismo. Una suerte de vuelta al estado de naturaleza.

15 Para Kant el pacto es inescrutable (trascendente) y no histórico como en Locke. Kant cierra la puerta al derecho de resistencia apelando a una instancia supraestatal (cuasi una apelación al cielo).

16 En sentido general, derechos son todos los derechos fundamentales, patrimoniales, sociales, etcétera, como expectativas positivas, prestativas o negativas (de no-agresión, prohibiciones). Lo anterior supone la existencia de deberes y derechos constitucionales (garantía 1: leyes) y de una norma positiva que resguarda las garantía 1 (garantía 2: operativización de la ley a través de normas específicas). Por ejemplo: si falta la garantía 1 cómo sería posible obtener la garantía 2. Es decir, si no existe derecho al trabajo cómo se podría legislar sobre el trabajo. 
En primer lugar, cuando hablamos de derechos individuales (humanos) y fundamentales hacemos alusión a los derechos "estampados"en las declaraciones y Constituciones de los Estados, o sea, hablamos de derechos positivos. El derecho de la sociedad moderna es el derecho positivo (H. Kelsen, 1952). En segundo lugar, aun considerando lo importante que resulta en la actualidad la rediscusión de los fundamentos del derecho para la hermenéutica, instrumentalización o concretización de los derechos (humanos), indicamos que no es de nuestro interés ocuparnos de estos problemas aquí, sino más bien acentuar la idea planteada por $\mathrm{N}$. Bobbio, en el sentido que no es tan necesario fundamentar los derechos humanos, como sí garantizarlos, y para ello éstos deben formar parte de un programa condicional.

No está de más recordar también que los derechos y las garantías individuales son el resultado de procesos de afirmación del derecho a la vida en sus múltiples manifestaciones (social, económica, cultural, afectiva, etcétera). Dicho en otras palabras, son conquistas evolutivas, producto de resistencias, del reconocimiento de la diversidad, en fin, del resultado de luchas de personas y grupos humanos que sufrieron en carne propia la violación de estos derechos. Porque es sabido que nunca en la historia derecho alguno fue reconocido, respetado y aplicado simplemente por constar apriorísticamente en una declaración o Constitución. Ésta, en cuanto texto e instrumento, es sólo una guía que orienta, que crea un horizonte para la expectativa, una autorrepresentación de la sociedad, pero sin efectividad es letra muerta. La Constitución es por tanto, y en última instancia, un acoplamiento estructural entre el sistema del derecho y de la política como señala Luhmann. Volveremos sobre este punto.

Ahora, si la Constitución es el estatuto jurídico de lo político, debemos tener presente que allí los derechos no están consignados por casualidad, ya sea que se trate de reivindicaciones o nuevos derechos. Son adquisiciones, perfeccionamientos continuos que van aumentando el grado de complejidad y exigencia social. De forma tal, que en cada proceso de constitucionalización se avanza un nuevo paso, pero éste se consolida sólo cuando esos derechos declarados se hacen universalmente operativos. ${ }^{17}$ Es decir, garantizan la construcción de ciudadanía, la acumulación

17 Es decir, proporcionar los criterios base sobre los cuales estos derechos puedan perseguirse y realizarse, lo cual implica a su vez estipular cómo se entiende administrar el acceso a los bienes escasos o la composición de conflictos jurídicos (reglas). En este 
progresiva de derechos y su abierta intervención, allí donde ésta no puede realizarse. ${ }^{18}$

Ciertamente, en el actual contexto de la globalización se persigue también afirmar nuevos derechos, lo cual representa grandes desafíos para el propio sistema del derecho moderno, en el sentido que buscan articularse y asignarse sobre una nueva titularidad que es difusa. Esta afirmación de derechos se vincula en general con temas como la paz, el medio ambiente, el desarrollo, la propiedad sobre el patrimonio común de la humani-

sentido, y con el objetivo de observar el proceso de constitucionalización de los derechos, podemos utilizar el esquema de la evolución y generación de la fenomenología ciudadana propuesto por T. H. Marshall. La teoría de Marshall se revela indudablemente fecunda en la segunda mitad de siglo XX, al proporcionar una nueva concepción de ciudadanía con relación a los derechos humanos a partir de referencias sociológicas y filosóficas para el análisis jurídico, su gran efectividad e inefectividad y su relación con los conflictos, con la economía de mercado, con la democracia política, etcétera. Esta propuesta persigue articular una conexión coherente entre la temática de los derechos humanos, la ciudadanía y la democracia, con el objetivo de superar y especificar un corte tajante entre status negativus y status positivus (como señala en su taxonomía Jellinek), o entre el derecho individual y el derecho político establecido formalmente por la Declaración Francesa de 1789 (la cual hace explicita la diferencia entre los derechos del hombre y los derechos del ciudadano). En la concepción de Marshall, los derechos fundamentales se revelan consecutivamente en la modernidad a través de tres diferentes generaciones: derechos individuales, derechos políticos y derechos sociales. Tales instituciones resultan básicas para sostener empíricamente las garantías individuales en la modernidad. De ahí que para Marshall haya un tipo de igualdad social asociada a la membresía, a la pertenencia a una determinada comunidad; aun cuando esta idea esté en contradicción con la consecuente división de clases en un orden social capitalista. No obstante, la ciudadanía alteraría los patrones de desigualdad social toda vez que hay una tendencia a la equiparación en la distribución del ingreso y hacia la creación de elementos identitarios que posibilitan precisamente la igualdad (cultura y universalización de la ciudadanía).

18 En última instancia, lo que Marshall intenta es explicar cuáles son los mecanismos internos de legitimación del sistema capitalista, es decir: quiénes están incluidos y por qué, con el claro objetivo de generar y consolidar la cohesión y un tipo de orden social. En tal sentido, el tema de las expectativas sobre el aumento de la calidad de vida produce mayores lealtades hacia la comunidad de pertenencia. Marshall pone las bases para el despliegue del Estado de bienestar (en un contexto de pleno empleo donde el Estado es visto como el principal responsable y generador del bienestar ). Sobre esto véase Marshall, Thomas H., Class, Citizenship and Social Development, Doubleday and Company, 1965, también en Marshall, T. H. y Tom Bottomore, Ciudadanía y clase social, Madrid, Alianza Editorial, 1998. 
dad, las nuevas biotecnologías, el derecho a la comunicación, y la diversidad sexual entre otros. ${ }^{19}$

Como es lógico, todos estos temas trascienden los límites de los institutos jurídicos hasta hoy concebidos y, a la vez, promueven y, paradójicamente, presuponen una nueva praxis de la ciudadanía, así como la redefinición del espacio público y la globalización política (ciudadanía cosmopolita), cuestionando profundamente al sistema democrático y a sus referentes economicistas, sociales y también culturales; todo lo cual pone en jaque a la propia modernidad, a sus estructuras y su operacionalidad, manifestando también el necesario debate sobre el riesgo en la sociedad moderna. Reconocer, por ejemplo, la violencia estructural de la sociedad moderna, las idiosincrasias del operar de los sistemas, la falibilidad de las utopías, lo cual ciertamente puede ser un proceso violento y doloroso, pero emancipador, toda vez que la realidad, por dura que sea, puede ser más bella que los tonos nostálgicos de la ingenuidad.

En este escenario, emergen nuevas críticas a la modernidad y a la manera que han adoptado sus formas institucionales. ${ }^{20}$ Críticas que en la ac-

19 Se habla incluso de derechos posmateriales en lo que sería una cuarta o quinta generación de derechos. Bobbio, Norberto, L'età dei deritti, Italia, Einauidi Editore, 1990.

20 Críticas que se conjugan con la tradición, desde Nietzsche pasando por la "racionalidad burocrática" de Weber, la "sociedad administrada" de Adorno, hasta el "poder disciplinar" y la "normalización tecno-científica" con Castoriadis y Foucault. Para Foucault el poder es una multiplicidad de relaciones de fuerza inmanentes al dominio en que se ejercen; relaciones no externas a los procesos económicos, al conocimiento o a las relaciones sexuales — inmanentes -; que no se adquiere, ni se arranca, ni se comparte. Aquí parece no haber una oposición binaria entre dominadores y dominados; entonces resulta inútil buscar el estado mayor que preside la racionalidad del poder, ni la casta que gobierna, ni los grupos que controlan los aparatos del Estado. Por lo tanto, donde hay poder hay resistencia, por eso mismo ésta no es exterior el poder; las resistencias forman un reverso siempre pasivo de la dominación esencial condenando al sujeto a la derrota infinita. Foucault ha edificado un modelo conservador, un aparato ideológico que permite transformar el impulso más subversivo y disolvente del criminal y del esquizofrénico en un logogrifo estructuralista de la inmanencia del poder. Como señala Roger Bartra, es evidente que se trata de un programa conservador, desmovilizador y pesimista. Con este modelo se suprime la lucha de clases, pero ya no por mediación dialéctica, a la manera hegeliana, sino por sustitución y transposición a la manera freudiana, entre el significado dominante y el significado revelado por medio de una decodificación del significante se ha perdido un elemento esencial que es precisamente la dominación. Como las máscaras de un prestidigitador, los signos aparecen y desaparecen ocultando siempre la cara, en la que el poder aparece desmigajado en un número infinito de fragmentos entrelazados. 
tualidad apuntan al desequilibrio entre "regulación" y "emancipación", a través de la colonización de la racionalidad cognitivo-instrumental de las ciencias, en detrimento de las demás racionalidades (Habermas, Boaventura de Sousa, Rancière, Castoriadis), abarcando el proceso de crisis del antiguo humanismo iluminista romántico y también de los grandes sistemas escatológicos o evolucionistas, como el idealismo, el materialismo dialéctico y el positivismo, los cuales no están en posición de afrontar los problemas de la compleja sociedad moderna. Recordemos que ya desde la mitad del pasado siglo el ideario moderno pasa a ser pensado no más en oposición a la antigüedad, sino en oposición a la eternidad. Lo moderno como transitorio, fugaz, siempre diverso y contingente. ${ }^{21}$

En tal sentido, en nuestros días, confrontados a la inoperatividad de las arcaicas semánticas de la modernidad se han ido afirmando análisis de tipo de-constructivo y la formulación de cuestiones de tipo reflexivo-constructivista. Estas contribuciones teóricas indican y ponen el acento en la circularidad y paradojas, en tanto características estructurales de la sociedad moderna (en tanto sistema universal de comunicación social, Luhmann; complejidad, von Foester, Morin; autopoisis Maturana y Varela), lo cual les permite demostrar que en la artificialidad y contingencia de los productos de la modernidad se encuentran sedimentos evolutivos que aún no han sido plenamente desplegados, por la inercia que se opone a los procesos de diferenciación. Es decir, nos invitan a repensar el proceso de adquisiciones evolutivas de la modernidad de la sociedad moderna. ${ }^{22}$

Observar las adquisiciones evolutivas y su proceso es cuestión central para entender la diferenciación del sistema político y del derecho en la

21 Al respecto véase el interesante ensayo del filósofo francés Rancière, Jacques, Aux bords du politique, París, Osiris, 1990.

22 Hablamos, en general, de diferenciación cuando un sistema se diferencia del propio entorno al trazar sus límites diferenciados, haciendo posible a éste observar que existen otros sistemas en el propio entorno. Por ejemplo, "en el entorno de la sociedad existen sistemas síquicos y sistemas orgánicos". La diferenciación del entorno no depende del sistema, sin embargo asume formas particulares según las distinciones que orientan la observación del sistema. Ahora, la característica central de este proceso es que cada función que forma parte del esquema de diferenciación sirva a un solo sistema parcial de la sociedad. De otra manera esta forma de diferenciación no se realizaría y aunque, evolutivamente, se pudiese hablar de división del trabajo social, diferenciación de roles o de una multiplicidad de distinciones semánticas sería implausible afirmar una diferenciación funcional de este tipo; toda vez que el factor que posibilita operar dicha diferenciación es la función comunicativa (código). 
actualidad. Ello porque las adquisiciones evolutivas de la modernidad generan un incremento, pero también una disminución, de las prescripciones sociopolíticas del Estado. Baste pensar en el incremento de las prescripciones jurídicas $\mathrm{y}$, consecuentemente, de las atribuciones del Estado, así como en la disminución de la efectividad del derecho y de las prestaciones estatales (derrumbe del Estado de bienestar en Europa y del Estado de compromiso, desarrollista o estabilizador en América Latina). Es decir, en el problema del reconocimiento formal de nuevos derechos y en la evidente negación material (operativa) de tales derechos, y esto precisamente en la era de los derechos y, sobre todo, en la era de los nuevos derechos (N. Bobbio).

Como se ha indicado, el constitucionalismo moderno se funda, precisamente, asumiendo la presunción de una perspectiva individualista, en la cual los primeros límites a los ejercicios del poder estatal estaban en la esfera de una autonomía privada de los individuos en cuanto tales (lo que sería exactamente la contrapartida de la llamada autonomía pública de los ciudadanos). Ese reconocimiento de los derechos de los individuos como anteriores a toda forma de organización política, aun en el campo del pensamiento iusnaturalista, constituye un primer vínculo al poder. Pero el aumento de evolución y complejidad en la moderna sociedad, y consecuentemente las nuevas demandas que emergen cotidianamente de la sociedad, generan a su vez estructuras siempre mayores y más complejas para la superación de estos problemas, estructuras que a su vez producen más (y nuevos) problemas.

Por lo tanto, la disponibilidad, sin preconceptos, que permite observar la morfogénesis de la complejidad de la sociedad moderna, nos puede conducir a afirmar, como señala De Giorgi, que en la sociedad actual es posible la democracia y sus ciudadanos porque es posible tomar decisiones que incrementan continuamente las posibilidades de posteriores elecciones. Como también es posible alcanzar, a través del derecho, niveles de congruencia en las decisiones que sean adecuados a la complejidad del ambiente, utilizando las diferencias existentes para reducir los obstáculos a la diferenciación, con la certeza - claro está- que en este proceso se generarán nuevas distinciones, nuevas diferencias, nuevas inclusiones y exclusiones $\mathrm{y}$, en fin, nuevas periferias.

Asumiendo un razonamiento tal, y visto que en el presente todo puede ser también diverso, es dable hipotetizar que los procesos de violencia, 
exclusión y degradación social pueden ser al mismo tiempo formas de inclusión de la exclusión, puesto que en esta sociedad es posible lo que en otras era impensable. Pensemos solamente en el amor, que siendo una comunicación improbable, acontece, aun cuando siempre representa un riesgo. ${ }^{23}$

\section{DERECHO, CIUDADANÍA Y SOCIEDAD}

Hoy en día y de cara a la compleja realidad de la sociedad moderna, la apelación a los derechos individuales y la ciudadanía está íntimamente vinculada con conceptos y términos utilizados muy frecuentemente en la retórica política y en el discurso de las ciencias sociales: sociedad civil, ciudadanía, democracia y globalización. Sin embargo, a mayor ampliación del debate, más oscuro se vuelven dichos conceptos. Es decir, cuanto más se habla - por ejemplo- de sociedad civil y del proceso de globalización, tanto mayor es la multiplicidad de sentidos conferidos a tales expresiones.

Si nos detenemos, por ejemplo, en la semántica del concepto sociedad civil, en un intento de síntesis necesariamente simplificadora, podemos observar que la situación actual de la llamada sociedad civil y de sus manifestaciones (movimientos sociales, de protesta, organizaciones civiles, etcétera) podría ser descrita como en estado de "balcanización". Dicho en otras palabras, en un estado de fragmentación, despolitización, localismo y corporativismo clientelar. Esta situación se torna más dramática si se considera el carácter polifacético del termino "sociedad civil", que de suyo comporta una gran dosis de ambigüedad, pues a fin de cuentas ¿qué podríamos entender en la actualidad por sociedad, por civil?

Mirando hacia atrás, con la perspectiva que ofrece la historia, vemos que en la tradición griega el concepto koinonía politiké fue acuñado por Aristóteles para indicar la diferencia entre sociedad doméstica (oikós) y sociedad citadina. En los albores del medioevo Agostino, en La ciudad de Dios, rescatará esta idea de las dos esferas diferenciadas; la ciudad de Dios y la cuidad terrena, formada esta última por la unión de hombres asociados en un común reconocimiento de derechos y de sus intereses (sociedad civil). Más tarde, Santo Tomasso retomará la premisa del derecho y la justicia como elementos fundamentales para potenciar los prin-

23 Comunicación personal con Raffaele De Giorgi, 2002. 
cipios generales de la ley humana en sociedad. ${ }^{24}$ Pero será sólo con el despliegue de la ilustración, en la época moderna, que la concepción de sociedad civil emerja, en lo fundamental de la distinción articulada por Hegel, bajo la formula sociedad/Estado.

Tomando como base aquella representación que utiliza la distinción entre sociedad civil, entendida como el universo de las necesidades o el reino de la individualidad (siguiendo la cara idealización tocquevilleana), y el Estado entendido como la sociedad política (el lugar de la centralización de las decisiones y del gobierno de la diversidad: descripción que hizo plausible apuntalar, además, el primado del sistema político como el vértice que controlará al conjunto del sistema social — la totalidad-) era lógico, entonces, arribar a la idea de la política como un sistema central de decisiones sobre recursos controlados por el derecho, el cual basado en universales principios garantizaría la justicia de las distribuciones.

Estos presupuestos ilustrados, que sirvieron de cimiento para la arquitectura constitucional de la sociedad moderna, encontraron su expresión más alta en el ideal democrático y en la estructura del parlamentarismo. Una estructura asentaba en una refinada ingeniería constitucional que debía permitir la representación de intereses, la defensa del bien común y la tutela de la diversidad entendida como garantía del derecho de las minorías; todo lo cual, evidentemente, presuponía la centralidad de la idea de nación y la posibilidad de la representación de un centro decisorio capaz de representar el interés general.

Como se ha indicado, frecuentemente y signado por la tradición, el concepto de sociedad civil se refiere primordialmente a la relación socie-

24 En parte, esta ideas serán profundizadas por los comunitaristas a partir del modelo histórico que surge en los claustros (siglos XII-XIII), en las cerradas comunidades religiosas del tardo medioevo, en pos de las luchas colectivas entre los religiosos y la aristocracia (la lucha de poder divino contra el poder terrenal). Grupos que se autoconstruyen y luchan por su autonomía. Aquí, autonomía significaba libertad; autonomía de grupo cuyos iguales miembros gozan de los mismos derechos y deberes pero donde la adscripción al grupo no es voluntaria, es determinada en tanto perteneciente a cierto grupo (sentimiento de comunidad como valor intrínseco del colectivo). Para los comunitaristas el éxito de este proceso fue la constitución de la actual sociedad civil. Debemos considerar, sin embargo, que retrospectivamente encontramos antecedentes de estos movimientos religiosos ya en el helenismo. Luhmann, Niklas, Sistemas sociales. Lineamientos para una teoría general, México, Alianza Editorial-Universidad Iberoamericana, p. 399. 
dad-Estado. ${ }^{25}$ Entendida en su expresión más simple, tal distinción busca señalar la diferencia existente entre la gente que desempeña sus funciones en el ámbito de las organizaciones formales del sistema político y el conjunto de individuos que están "fuera" de dichas organizaciones y que, por lo tanto, constituyen "la sociedad". Tiempo atrás su uso pretendía además llamar la atención sobre los cambios en la sociedad misma, ofreciendo una lectura crítica de la nueva estructura social que emergió fundamentalmente en Europa del este y América Latina tras el ajuste de las estructuras económicas y la lucha contra las dictaduras militares.

En este contexto el llamado al fortalecimiento de la sociedad civil buscaba contraponerse, lógicamente, a la desintegración del tejido social. Era una invocación que remitía, en último término, a la lucha contra el Estado dictatorial y/o autoritario y la consecuente lucha contra la exclusión social. ${ }^{26}$ El renacimiento de la idea de sociedad civil se constituyó en la piedra angular para el análisis de los procesos de democratización en las sociedades contemporáneas. ${ }^{27}$ Resucitada, en un primer momento, para connotar una multiplicidad de movimientos sociales de Europa del este, fue luego utilizada con profusión como parte del arsenal teórico con el cual se estudiaron y explicaron los procesos de transicio-

25 Distinción que, evidentemente, sobrepasa los ámbitos de la disciplina sociología y remite, vía la fílosofía política, a más de dos mil años de tradición. En el origen de dicha conceptualización filosófica se encuentra la distinción entre espacio público de la vida política y la economía doméstica. Con los griegos dicha distinción ganó un componente ético según el cual la naturaleza del ser humano sólo podía alcanzar su perfección (vida buena) en la comunidad política. Pero en la actualidad, incluso para fines sociológicos, el concepto filosófico de la koinonía politiké (así como sus derivaciones modernas cristalizadas en el concepto de "sociedad civil") resulta insuficiente. Por lo mismo, cuando con motivo de reconstrucciones históricas se reanuda el empleo de dichos conceptos, lo que termina por escaparse, en palabras de Luhmann, es la realidad.

26 Lechner, Norbert, "Sociedad civil: revisión crítica de un concepto", en Rincón Gallardo, G. (coord.), Partidos políticos y sociedad civil, México, Centro de Estudios sobre la Reforma del Estado, 1995. Favoreciendo la denuncia de un Estado que viola los derechos humanos, reprime la participación ciudadana y desmantela las organizaciones sociales. Lechner, Norbert, "La (problemática) invocación de la sociedad civil”, México, año 3, núm. 5, 1994, pp. 132-138.

27 Habermas, Jürgen, Fatti e norme. Contributi a una teoria discorsiva del diritto e della democrazia, Milán, Guerini Editore, 1992. 
nes y cambios políticos en Latinoamérica (Cono Sur, Centroamérica y México). ${ }^{28}$

Sin embargo, creemos importante aclarar qué implica la así llamada sociedad civil; qué es lo que se denota y qué es posible observar cuando se habla de sociedad civil. Como también es importante, no confundir la capacidad para organizarse con la posibilidad de transformar a voluntad el sistema de la sociedad por el sólo hecho de participar, ${ }^{29}$ pues una cosa es el reconocimiento de la auto-organización de la sociedad (como entorno ecológico de los sistemas sociales), y otra muy distinta es la estabilización de sus expectativas a través de estructuras decisionales amparadas por la ley (limitaciones normativas de los sistemas que son centrales en la medida que permiten conjugar expectativas desarrolladas en el entorno con la normativa política-administrativa y además participar del poder negativo).

Quizás ésta sea la razón por la cual el uso de un concepto tan reificado de sociedad (aquel sistema que se compone de las acciones "recíprocas" entre individuos) hace difícil entender la dinámica de la sociedad moder-

28 Lechner señala que la temática de la sociedad se instala a mediados de los años setenta a raíz de los golpes militares en el Cono Sur. Se recurre entonces al término con intención polémica para explicar la antinomia básica de una sociedad civil que se contrapone al Estado autoritario. La invocación de la sociedad civil tiene entonces una clara connotación antiautoritaria, no obstante el concepto continúa siendo poco claro y no unívoco. Por lo tanto, y aun considerando el potencial transformador de los procesos de aprendizaje normativo, se debe evitar la tentación de mistificar la sociedad civil y también la inflación comunicativa de los valores y de los derechos en la estructura de la sociedad moderna. En el estudio de la obra de los transitólogos (J. Linz, F. Schmitter, G. O'Donell, M. A. Garretón), de los críticos y de los políticos de uno u otro bando, un concepto recurrente y relevante es precisamente el de sociedad civil y sus agregados: democracia, actores y movimientos, etcétera. En dichas conceptualizaciones el soporte irreductible de las condiciones para la democracia es el factor "sociedad civil", imbricada de forma sui generis con el concepto, tan en boga hoy en día, de gobernabilidad, que entre disquisición y disquisición teórica termina homologado, frecuentemente, con democracia.

29 Un buen y dramático ejemplo al respecto está dado por la capacidad que tuvieron las manifestaciones de la sociedad civil (movimientos sociales y de protesta) para presionar por la salida de los dictadores militares en el Cono Sur, como también la imposibilidad para informar un programa condicional en función de la transición política, lo cual aún tiene ribetes dantescos, sobre todo lo relacionado con los temas de la justicia y de los derechos humanos. Sobre esto, véase de Zamorano, Raúl, Entre la teoría y la acción. Dilemas sobre la acción colectiva popular Santiago de Chile: 1988-1992, México, Juan Pablos Editor, 2001 (en particular tercera parte). 
na, pues la misma noción de sociedad civil ha adquirido un uso tan múltiple que ha perdido todo significado preciso. ${ }^{30}$

Recordemos que luego del derrumbe del sujeto histórico en la década de los setenta y tras el ulterior fracaso de la "vuelta del actor" y de todos los intentos por sobre-codificar el vilipendiado concepto de clase social, en busca del "sujeto perdido" (nuevos movimientos sociales, "nuevo sujeto histórico", redes sociales), se retoma el polémico concepto de sociedad civil para intentar describir una realidad del todo diversa, con nuevas complejidades, y encajarla en gastadas casillas teóricas. Esto, que de por sí es problemático, se torna más complicado sobre todo cuando en la actualidad existe el reconocimiento tácito que la "sociedad civil" se ha subdividido de forma tal que expresa toda clase de oposiciones, haciendo prácticamente imposible aprehender su continente y contenido.

Además, si se asume que la sociedad civil, en cuanto tal, es una abstracción que aun cuando pueda "sugerir" programas condicionales ${ }^{31}$ no tiene capacidad para su estipulación (ni para su operatividad), ${ }^{32}$ lógicamente ésta tampoco puede ejercer funciones cívicas básicas, ni tener una voluntad en abstracto. Será sólo a través de las organizaciones que las

$30 \mathrm{Al}$ igual que conceptos como público/privado: construcciones difusas, las cuales no están claramente delimitadas.

31 Los programas condicionales son criterios operativos, de decisión; son las reglas del juego. Es decir, los programas condicionales son un complejo de condiciones de veracidad y aceptación de la conducta. Son condiciones anticipadas que hacen plausible la acción: condiciones motivacionales, comunicativas, espaciales, funcionales y operativas. Véase Luhmann, Niklas, Sistemas sociales: Lineamientos para una teoría general, cit, nota 24. Es necesario subrayar que ni los valores ni los derechos humanos se proponen en la forma de indicaciones programáticas. Es decir, no proporcionan en modo alguno los criterios base sobre los cuales ellos puedan perseguirse y realizarse. Como señala Corsi, ser autores de la paz no aclara si se quiere proceder a la compra de armas o a la protesta "no violenta". Exaltar la igualdad todavía no dice nada sobre cómo se entiende administrar el acceso a los bienes escasos o la composición de conflictos jurídicos, ni cómo se quiere ayudar a los pueblos que viven en condición de indigencia o de malnutrición. Los valores, pues, no son programas decisionales, son valores y nada más (expectativas). Sobre esto véase el interesante trabajo de Corsi, Giancarlo, "Valores y derechos fundamentales en perspectiva sociológica", Revista Metapolítica, México, núm. 20, 2001.

32 Por ejemplo, los llamados movimientos sociales o los movimientos de protesta producen una gran cantidad de comunicación sobre decisiones (irritando al sistema político) pero no deciden. Sólo al interior de las organizaciones y en los sistemas se decide. $\mathrm{Al}$ respecto Corsi, Giancarlo, Sistemi che apprendono, Lecce, Pensa Multimedia, 1998 y Luhmann, Niklas, Orgnizzazione e decisione, Milán, Bruno Mondadori, 2005. 
expectativas y los temas emergentes puedan hacerse políticamente efectivos (institucionalmente) y, por lo tanto, allí la existencia efectiva del imperio de la ley es supuesta como un prerrequisito existencial de la llamada sociedad civil, como han señalado acertadamente - entre otros - J. Habermas, N. Bobbio. ${ }^{33}$ Resulta obvio entonces que cualquier impulso de una mayor participación de la sociedad en las decisiones que tienen que ver con los modelos reales de poder político, si no tiene como soporte una estructura normativa institucional-operativa, es sólo retórica cuando no demagógica, lo cual además, profundiza y potencia en los hechos las decisiones de grupos particulares con respecto al tipo de democracia que conviene a los países. ${ }^{34}$

Es decir, favorece las orientaciones de grupos que acatan los parámetros de la democracia tutelada y liberal ("gobernabilidad"), para llevar a cabo elecciones con la mayor concurrencia posible, en un marco de consensos y pactos que garanticen el modelo económico, que se apegan a ciertas normas formales y que tienen supuestamente que ver con las promesas de la democracia, lo cual no quiere decir que deban ser gobiernos democráticos. Porque aun cuando en la actualidad se valore la democracia, existe una creciente insatisfacción y desconfianza hacia los regímenes políticos; sobre todo en las "democracias electorales", donde toda participación perece iniciar y terminar con el voto (particularmente en América Latina). ${ }^{35}$

33 Siguiendo la gramática de Arato y Cohen, como estructuras de los derechos. La operatividad del sistema judicial y los aparatos que garantizan la reproducción sociocultural del sistema social. Cohen, Jean y Andrew Arato, Sociedad civil y teoría política, México, Fondo de Cultura Económica, 2000. Es el sistema político particularmente en el Parlamento, donde se recogen y presentan las iniciativas de ley que condensan los temas y aspiraciones del sistema social (entorno).

34 Grupos que además se han apoderado y privatizado de las estructuras del Estado.

35 Bobbio, Norberto, Il futuro della democrazia. Una difesa delle regole del gioco, Turín, Einaudi-Nuovo Politecnico, 1984. 


\section{EL PROBLEMA POLÍTICO-DEMOCRÁTICO Y CONSTITUCIONAL EN LA MODERNA SOCIEDAD LATINOAMERICANA}

\section{Introducción}

Reflexionando en particular sobre las contribuciones de la sociología de los sistemas sociales asumimos la idea de que la sociedad actual está basada sobre una diferenciación de tipo funcional. Esto significa que el criterio primario sobre cuya base la sociedad moderna se reproduce y en el cual cualquiera puede participar de la vida social, no es aquel discriminatorio y jerárquico que caracterizaba los antiguos órdenes sociales: diferenciación funcional significa que son los problemas de fondo de la sociedad aquellos llamados a orientar la comunicación (esto es, las funciones que deben ser adoptadas), y no la posición social de los individuos. ${ }^{36}$

Dando por descontada esta definición general, no se puede evitar plantear un problema: ¿por qué, luego que el continente latinoamericano ha superado en buena parte los conflictos de los decenios pasados y luego de haberse confiado a la fórmula política democrática, no es todavía posible agregar, desde el punto de vista operativo los ordenamientos jurídico-políticos existentes en el continente con aquellos manifiestos en los centros de la sociedad moderna?

A propósito, es claro que algunas diferencias radicales como aquella existente entre "la inclusión y la exclusión social" siempre han existido, pero solamente con la modernidad éstas se transforman en problema: desigualdad, pobreza, falta de oportunidades, a las cuales, se une un desor-

36 En este sentido, se asume que la función del sistema político no es más aquella de alcanzar la vita buona o el ideal de la perfección, sino simplemente coordinar decisiones vinculantes para todos: mientras que la función del derecho (que viene a operativizar las decisiones políticas) no se basa más sobre la estratificación social como criterio de construcción y composición de los conflictos, sino exclusivamente, sobre la base de programas propios a partir de un ideal de igualdad. Evidentemente, éstos son desarrollos evolutivos que impactan a la sociedad entera sin excepciones. Basta pensar en la palabra clave que ha dado vida a tantas esperanzas y ha alimentado un debate todavía en curso sobre las perspectivas de la sociedad mundial y, particularmente, de América Latina: democracia. Democracia que, en la actualidad, es sólo una de las formas de hacer operativo el poder político. Curiosamente, después de 2500 años, ésta ha pasado de ser entre las formas "menos malas" (Platón-Aristóteles), la mejor forma de orden político (recordemos que la política tiene que ver esencialmente la adquisición, mantenimiento y ampliación del poder). 
den generalizado que conduce a la fragmentación social, constatando las dramáticas condiciones de vida de un significativo porcentaje de la población mundial. Evidentemente se trata de un problema típico de esta época histórica. Entre los tantos efectos evolutivos que ha tenido la estructuración operativa de esta forma de diferenciación, de hecho, existe también un modo del todo diverso de observar y evaluar las diferencias territoriales y sociales.

\section{Nuestra modernidad: diferenciación y desdiferenciación funcional}

En el caso particular de América Latina, lugar geopolíticamente definido en "vías de desarrollo", la vivencia de la democracia en la periferia de la sociedad moderna se manifiesta con caracteres específicos, ligados obviamente a su historia. ${ }^{37}$ En nuestra región la forma de actualizar el ethos de la modernidad, a diferencia de las sociedades centrales (caracterizadas por una mayor diferenciación funcional policéntrica, fundamentalmente operativa), ha estado signada por un tipo de diferenciación funcional de carácter concéntrico. Es decir, un orden social que a pesar de ser concebido bajo criterios de modernidad, es guiado en sus operaciones fundamentales por la lógica parcial de un centro de regulación global (sociedades concéntricas), ${ }^{38}$ lo que en términos prácticos significa que las sociedades latinoamericanas funcionan desdiferenciadamente, sobre un plano funcionalmente diferenciado, pero con los criterios de un orden estratificado. Dicho en otras palabras, las sociedades latinoamericanas funcionan en el contexto de órdenes sociales diferenciados y desdiferenciados al mismo tiempo. ${ }^{39}$

37 Véase Mires, Fernando, op. cit., nota 9.

38 Mascareño, Aldo, "Teoría de sistemas de América Latina. Conceptos fundamentales para la descripción de una diferenciación funcional concéntrica", Persona y Sociedad, vol. XVIII, núm. 2, 2003. Los sistemas funcionales siguen operando con medios simbólicos, pero sus selecciones son intervenidas. Con esto se quiere decir que toda selección e indicación en un sistema funcional, al ser intervenidas, son remplazadas por las selecciones e indicaciones de otro sistema funcional. Esto se ejemplifica en la corrupción, el tráfico de influencias, las restricciones a la libertad de expresión o la definición del operar del mercado con base en objetivos políticos, etcétera.

39 La desdiferenciación social es el proceso que surge cuando las relaciones de interdependencia dejan a un lado los acoplamientos — pues éstos asegurarían la autonomía de los sistemas funcionales acoplados no generando desdiferenciación - y algún sistema 
Lógicamente, la diversa forma evolutiva de orden social, experimentada en América Latina, describe una estructuración de sistemas funcionales caracterizados también por diversos niveles de autonomía, en la cual, sistemas autónomos diferenciados bloquean o ponen obstáculos al despliegue autorreferencial de lógicas parciales en vías de diferenciación. De ahí deriva que la particularidad del orden social en estos países, en relación con los países de modernidades centrales o policéntricas, se ha caracterizado porque sus órdenes sociales están estructurados en torno a un sistema dominante. En este tipo de orden social el desarrollo autónomo de cada esfera se hizo dependiente del sistema central, y los acoplamientos se transformaron en procesos de desdiferenciación que han aumentado la complejidad para el despliegue de la especialización de otras funciones. Al respecto, pensemos por ejemplo, a la siempre difícil relación entre los procesos de industrialización, de la estructura de la propiedad territorial, de las formaciones de élites que concentran recursos sociales en modo exasperante (no sólo dinero sino también poder e influencia) a la enorme distancia que separa la materialidad de las relaciones sociales locales con las instituciones modernas, etcétera. ${ }^{40}$

Ciertamente reconocemos que, en el último tiempo, en América Latina los procesos democráticos han conocido una significativa revaloración y expansión. Como señala el Informe del PNUD 2004, estos procesos democráticos están avalados y se inscriben en el ideario de la concepción moderna, el cual apela y connota que todos los ciudadanos tienen igual derecho de participar en la toma de decisiones colectivas dentro del marco jurídico-institucional existente. Es decir, en el marco de un conjunto

funcional interviene las operaciones basales de otro sistema haciendo difusos los límites del sistema con su entorno.

40 En las sociedades centrales, lógicamente, esta gran adqusición evolutiva (transformación), estuvo caracterizada por la eliminación de la sociedad monárquica y la creación de una sociedad igualitaria en la que el lugar de cada cual dependiera del mérito (no del nacimiento), y en la cual los vínculos individuales se definen por medio del contrato (tipo legal-racional), no por vínculos personales. En otras palabras, por la preminencia de un orden social diferenciado por sobre un orden estratificado. Es decir, las posibilidades de mantener el elevado nivel de alternativas decisorias en el ámbito del sistema político, cuyo presupuesto es que los espacios de la decisión de los sistemas políticos modernos se encuentran cada vez más delimitados, la arquitectura conceptual que fundó el moderno Estado-nación — asentada en conceptos de participación, consenso, bien común y representación de intereses - es incapaz de describir el potencial moderno de complejidad en la actual estructura del sistema político. 
de atributos procedimentales, los cuales, según las condiciones estipuladas por R. Dahl, se caracterizan porque las autoridades son electas, existen elecciones libres y justas, el sufragio es inclusivo (universal), todos tienen derecho a ser elegidos a cargos electos, existe libertad de expresión, información alternativa y libertad de asociación. ${ }^{41}$

Sin embargo, y tal como el propio Informe lo reconoce, todavía persisten graves problemas en la implementación operativa de los procedimientos y estructuras disponibles para el ejercicio democrático. Evidentemente esto tiene que ver con el hecho que en la región ha sido práctica permanente de muchos gobiernos, los cuales amparados en la realización "procedimental" de elecciones más o menos "democráticas" (Brasil y México durante gran parte del siglo XX, el Chile del primer Alessandri y de González Videla, el Perú de Odría y de Fujimori, la Argentina de Perón y de Ménem, Centroamérica en general, etcétera), certifican a sus países como democráticos, pero siempre instrumentalizando las reglas y los procedimientos, precisamente, por la ausencia de interacciones institucionalizadas estables y de mecanismos de supervisión y control de los poderes Legislativo y Judicial (accountability: O'Donnell).

Recordemos que en la conformación del Estado-nación en América Latina, la adquisición evolutiva del proceso de institucionalización y diferenciación social (proceso de civilización, N. Elias) estuvo caracterizada por crecientes y desgarradores procesos que fueron complejizando sus estructuras sociales. Históricamente podemos sostener que la conformación del Estado clásico en la región se ha caracterizado por dos constantes. De una parte, por la concepción del Estado como creador de sociedad, donde los actores se constituyeron por y en referencia a éste (un Estado centralizado, regulador y mediador). ${ }^{42}$ De otra, por la veloz implementación de estrategias de modernización, cuya rapidez ha ido configurado formas híbridas de organización estatal, destruyendo o desvane-

41 Dahl, Robert, Un prefacio a la teoría democrática, México, Ediciones Gernika, 1987; La democracia y sus críticos, Barcelona, Paidós, 1993; La poliarquía. Participación y oposición, México, REI Editores, 1993.

42 Debemos considerar, además, que la historia del constitucionalismo latinoamericano (en tanto contenedor de la idea democrática) está llena de "reformas" que han servido más para perpetuar el status quo que para cambiarlo, mientras que las elites locales han estado por mucho tiempo enamoradas de la idea de la modernización copiando las instituciones del mundo atlántico (el caso mexicano - aunque no es único, resulta paradigmático al respecto-). 
ciendo las representaciones sociales con relación al orden social (distancia entre el país ideal y el país real), lo cual ha imposibilitado la sedimentación o estructuración de las expectativas; aun cuando, en general, se haya depositado una gran esperanza en el sentido que con el trasplante e importación de instituciones, Constituciones y procedimientos se promovería rápidamente el trance a la ansiada modernidad política y económica. ${ }^{43}$

De ahí también que la estructuración e institucionalización de las expectativas (cognitivas y normativas), por lo general, se ha quedado a medio camino, cuando no empantanada, sin lograr constituir el correlato necesario de un orden social cada vez más diferenciado, llegando a una situación en donde tenemos procesos de modernización pero no-modernidad $^{44} \mathrm{o}$, dicho con otras palabras, tenemos sistemas diferenciados funcionalmente pero no en su operación, en su factualidad de operar. ${ }^{45}$

Sabido es además, que en la región las democracias han operado recursivamente con la lógica de que "quien gana la elección presidencial queda facultado para hacer lo que mejor le convenga, limitado sólo por las duras realidades de las relaciones de poder existentes y por el factor temporal de ejercicio del gobierno". Es decir, más que democracias ma-

43 Fenómeno nada novedoso, más aún si consideramos que la "sociedad civil" en el continente, no puede ser pensada en términos de agrupaciones de ciudadanos independientes y autónomos que se unen para formar el Estado que regule sus compromisos y les proteja (modelo típico de Estados Unidos, que tanto fascinó a Tocqueville). Por el contrario, en nuestros países el poder - en manos de una élite, descendiente en su mayoría del colonialismo imperial-, se articula en función de generar el Estado-nación (homogeneizar el lenguaje, ciertos valores y concepciones, símbolos y patrones culturales) y a las organizaciones de la sociedad. De allí la referencia histórica de la sociedad civil al Estado y luego al sistema de partidos, como legítimo intermediario entre el Estado y ésta, lo cual fue instituyendo formas en que el sistema político, particularmente en la fuerte institucionalidad chilena, garantiza la dominación social, una eficiencia de la dominación que, haciéndose fuerte en el Estado, termina por subsumir a la organización social y ahogar a la llamada "sociedad civil" (corporativismo de Estado; Argentina, México).

44 Libertad, igualdad, fraternidad, participación, Estado democrático de derecho y todo el arsenal racionalista de la ilustración, que podemos resumir en las promesas a las que alude Norberto Bobbio (El futuro de la democracia).

45 Este factor entraña una diferencia fundamental respecto a los países europeos y los Estados Unidos, en donde hubo y hay una tradición de las formas democráticas, que constituyen el ethos de su cultura democrática (la institucionalización de expectativas - vía programas condicionales - como garantías individuales en un Estado de derecho). 
disonianas, éstas han sido democracias delegativas. ${ }^{46}$ Esta forma de democracia delegativa, como el propio O'Donnell observa, ha sido la continuación de las antiguas formas del caudillismo. ${ }^{47} \mathrm{Si}$ a lo anterior sumamos el hecho que durante las últimas décadas del siglo XX, amparados en las crecientes insuficiencias de la coordinación política, el discurso economicista propuso hacer del mercado el principio exclusivo de coordinación social, el resultado es que en la actualidad la situación política se ve agravada, cuando no es crítica, por el raquítico grado de institucionalización y por los estragos generados por la desciudadanización de la ciudadanía sepultada por el economicismo técnico y depredador.

Entonces, aun reconociendo que se han dado importantes avances con relación a la extensión del sufragio universal y la recurrencia de los procesos electorales (sobre todo desde 1980 y en el contexto de las nuevas democracias), en la región la democracia sigue siendo un problema porque algunos aspectos institucionales de la vida sociopolítica son deficientes, ya que o conservan las características típicas de movimentismo, clientelismo, corrupción y de la desdiferenciación corporativa o, porque en muchos casos perecieran definirse en la arena económica por la lógica costo-beneficio (racional choice), lo cual evidentemente dificulta la integración de intereses y la posibilidad de una real institucionalización de las expectativas y de las garantías individuales (no hay visión global,

46 O’Donnell, Guillermo, "Delegative Democracy", Journal of Democracy, núm. 5, 1997, p. 40

47 Que surgen principalmente con la crisis del Estado oligárquico (década de los treinta) e intentan presentar un proyecto político alternativo (institucionalización no pluralista, fusión entre el Estado, la política y la sociedad, por ejemplo México). Véase Alberti, Giorgio, La construcción de la democracia en América Latina, México, FLACSO, 1997. En Asia y Latinoamérica la evolución política se caracterizó por crecientes conflictos étnicos y clasistas, repetidos motines y violencia popular, frecuentes golpes de Estado militares, predominio de dirigentes personalistas inestables que a menudo adoptan desastrosas políticas económicas y sociales, una amplia y flagrante corrupción de ministros y empleados públicos, una violación arbitraria de los derechos y libertades de los ciudadanos, niveles decrecientes de eficacia y capacidad burocráticas, una difundida alineación de los grupos políticos urbanos, la pérdida de autoridad de legislaturas y tribunales, y la fragmentación (y a veces desintegración total) de partidos políticos con amplias bases de afiliados. Huntington, Samuel P., El orden político en las sociedades en cambio, Barcelona, Paidós, 1996. 
sino una carencia de contenidos y carácter propositivo del sistema político, no hay vínculos con el futuro). ${ }^{48}$

Tal se va configurando un orden social como una serie de islas o tribus (ciudadanos insertos en una sociedad pre-política), sin imágenes ni imaginarios, sólo el aquí, el ahora, con el código de la política corrompido por los intereses económicos y con la fragilidad e instrumentalización del derecho. Así, opacado por actores políticos y sociales significativos que intentan lograr sus objetivos por medios ilegales, inconstitucionales o antidemocráticos ${ }^{49}$ el sistema de la política carece entonces de capacidad de coordinación vinculante (prevaleciendo la simultaneidad) ${ }^{50}$ lo cual va multiplicando las incertidumbres y los problemas de decisión política en el sistema democrático (cómo acoplar la expectativa ciudadana y la toma de decisiones políticas). ${ }^{51}$

\section{Nuestra "sociedad civil"}

Al observar los procesos sociopolíticos de la sociedad latinoamericana en las últimas decadas, podemos distinguir con claridad dos momentos

48 Por ejemplo, en Perú, donde los gobiernos de la transición o las nuevas democracias, han seguido los derroteros históricos en su forma de entender y hacer política, es decir, han reavivado la lógica movimentista de corte esencialista (Movimiento Cambio Noventa de Fujimory), ahí se vuelve a ver la figura del líder carismático que guía a las masas en un escenario que, evidentemente, dista mucho del contexto donde se generaron los populismos clásicos. No pretendo sostener, como algunos suponen, que estamos frente a una suerte de neo-populismo, pues eso sería un anacronismo y un error político. Lo importante es constatar que se evidencian algunos fenómenos recurrentes en la historia política del continente, que es importante tener presentes a la hora del análisis. En el caso de Chile y sobre la cuidadanía card y la articulación social a través del mercado véase Moulian, Tomás, Chile actual. Anatomía de un mito, Santiago, LOM Ediciones, 1997.

49 Diamond, Larry y Plattner, Marc F. (comps.), El resurgimiento global de la democracia, México, UNAM-IIS, 1997, p. xix.

50 Obsérvese el proceso de las comunidades étnicas en Guatemala, el Zapatismo México, las acciones de piqueteros en Argentina, las movilizaciones campesinas de cocaleros en Bolivia, la movilizacion estudiantil en Chile.

51 ¿Cuál sería el nuevo rol del Estado, del derecho y de la llamada "sociedad civil" en el manejo de la incertidumbre, si se vive al instante, sin imagen de futuro? Cómo hacer un cálculo racional o "irracional", si tenemos diferentes temporalidades sociales, si la política tiene un ritmo diferente al de la economía y el derecho de la acción política ya no marca la hora para todos, pues la diferencia espacial unida a la temporal imposibilitan generar una agenda que canalice las expectativas y el juego democrático lo cual, paradojalmente, posibilita creer en la democracia sin que vivamos en democracia. 
claves en el accionar colectivo de la "sociedad civil". Un primer momento caracterizado por una fuerte incidencia de ésta en el campo político, a través de la irritación del sistema político vía movimientos de protesta. Movimientos articulados bajo una pluralidad y diversidad de formas de resistencia -iniciativas de base, organizaciones locales, movimientos populares, redes transnacionales de solidaridad, nuevas formas de internacionalismo obrero - que jugaron un rol fundamental en el debilitamiento o apertura de los regímenes dictatoriales y/o autoritarios y en la lucha por contrarrestar la exclusión social, abriendo espacios para la participación democrática y la construcción comunitaria, ofreciendo alternativas a las formas dominantes de desarrollo y conocimiento en pro de la inclusión social (Argentina, Chile, Guatemala, México, Nicaragua, Uruguay: años setenta-noventa).

El segundo momento, caracterizado por el cambio en su capacidad de irritar el sistema político y por la imposibilidad de conducir la demanda social y de aprovechar los espacios vacios (o aperturas de liberalización) dejadas por el régimen anterior. En esta fase la mayoría de las fuerzas sociales, políticas y culturales fueron sometidas a un proceso de jibarización por las oligarquías políticas en el poder, las cuales en función de salvaguardar la "gobernabilidad" y transición (siguiendo la receta de O'Donnell) lograron contener y someter el accionar colectivo, metiendo, literalmente, en una "jaula de hierro" la protesta social, debilitando las articulaciones populares y posibilitando a las nuevas alianzas en el poder, controlar dichos procesos (al respecto, el caso de la transición chilena sigue siendo paradigmático).

En consecuencia, el resultado de estos procesos de movilización y protesta social, más que consolidar la organización ciudadana tuvo por resultado la fragmentación y el desvanecimiento de dichas acciones de la escena pública, es como si ciertos futuros vitales hubieran quedado eliminados para siempre de la gama de posibilidades que porta la democracia. ${ }^{52}$ Sin embargo, ciertos valores, prácticas, circuitos y expectativas siguen vigentes. En algunos casos, se mantienen o se recrean a través de una mayor imbricación que se produce entre grupos sociales y las políticas sociales del Estado (lo cual además, en muchos casos, tiende a reproducir la relaciones clientelares). Hay también un segmento de organiza-

52 Steiner, George, En el Castillo de Barba Azul. Aproximación a un nuevo concepto de cultura, Barcelona, Gedisa, 1992. 
ciones sociales de carácter informal (mujeres, jóvenes, grupos étnicos), cuya tendencia a la autonomía se orienta hacia la generación de formas propias, articuladas fundamentalmente en el campo cultural.

Organizaciones que, en la lógica planteada por Cohen y Arato, podrían ser definidas por un marco institucional estabilizado precisamente por el derecho, cuya función es la vigilancia y demanda de la aplicación efectiva de los derechos existentes y, consecuentemente, la promoción de nuevos valores y derechos sociales, lo cual hace posible indicar y entender a la sociedad civil como aquel conjunto de instituciones y organizaciones creadas por el derecho y ligados a organismos civiles (sindicatos, asociaciones patronales, juntas de vecinos, juntas de padres, etcétera) y todos aquellos sectores que actúan por intereses sectoriales.

Desde nuestra perspectiva, hablamos específicamente de organizaciones para referirnos a un tipo de sistema social que se constituye con base en reglas de reconocimiento que lo vuelven identificable y le permiten especificar sus propias estructuras, delimitando así el ámbito y relación de sus operaciones, toda vez que las posibilidades de operar y decidir en las organizaciones está determinada por los programas condicionales, las vías de comunicación y estructuras de expectativas de las personas. ${ }^{53}$

Las organizaciones se caracterizan entonces por su estabilidad en el tiempo en función de algún propósito específico, con estructuras de relaciones que tienden a profesionalizar las acciones que realizan y que cuentan con un reconocimiento jurídico. Ahí podemos observar características organizativas de diversos tipos y relaciones al interior y entre otras organizaciones o grupos de personas. No obstante, y sea que nos movamos desde una perspectiva sistémica o de una óptica organizativa, se presentan siempre dos problemas fundamentales: aquel de la función y aquel del poder.

Con relación al sistema administrativo completo, de una parte nos debemos interrogar sobre la función en el ámbito del sistema general (esto es, para decirlo con una expresión corriente, sobre el objetivo público de la organización); de la otra, se debe poder observar la cuestión, claramente ya formulada por Weber, relativa al específico poder de aquel sistema administrativo que la aproximación funcional tiende sustancialmente a considerar como un simple instrumento. Al respecto, temas como la eficacia y la eficiencia privilegian el aspecto funcional y son entonces

53 Luhmann, Niklas, Orgnizzazione e decisione, cit., nota 32. 
examinados con la aproximación del funcionalismo sistémico. La temática relativa al poder administrativo y a la relación entre la administración y el ambiente pone en evidencia el aspecto político de nuestro tema y, por tanto, la pertinencia de la segunda de las dos grandes aproximaciones sociológicas (burocracia: Weber, poder: Marx). ${ }^{54}$

Pero es sabido que en la periferia de la sociedad moderna la existencia de la norma/derechos con aplicación universal y de justicia social es frágil en su implementación o, de plano, operativamente existe sólo para una inmensa minoría. ${ }^{55}$ Por ello debemos tener presente que en América Latina - incluso al interior de las organizaciones - la existencia del imperio de la ley no es un dato dado. En nuestras democracias los procesos de institucionalización siguen en etapa de consolidación (fragilidad en institucionalización y operatividad de los derechos civiles, políticos y sociales, lo cual profundiza las exclusiones), "generando todo tipo de subproductos colaterales" que van desde relaciones orientadas por la lógica

54 Sobre las organizaciones y su teoría véase March, J., H. Simon, Teoría de la organización, Barcelona, Ariel, 1981; Luhmann, Niklas, Organización y decisión. Autopoiésis, acción y entendimiento comunicativo, Barcelona, Anthropos Editorial, 1997. Mayntz señala que se puede entender mejor el significado del desarrollo de los subsistemas sociales si se piensa, al contrario, en una sociedad poco diferenciada. En una sociedad de este tipo el principio de unidad social se funda sobre la relación familiar o, generalmente, de parentela o vecindad; es entonces típico que la familia sea también la comunidad económica (tal vez una comunidad conjunta de producción y de consumo), y una comunidad cultural-religiosa, la administración se reduce por lo más al patrimonio doméstico. Al contrario, con la formación de subsistemas sociales, se desarrollan organizaciones funcionalmente especializadas: clase, partido, Parlamento, empresas, servicios, escuela. En estas organizaciones el individuo reconoce el rol de especialistas en vista al desempeño de funciones específicas. Considerada desde el punto de vista sistémico, la diferenciación del sistema social es un medio para aumentar su rendimiento y capacidad de sobrevivencia. La ventaja principal de la diferenciación es el dato de la especialización. Mayntz, Renate, Sociologia dell' amministrazione pubblica, Italia, Il Mulino, 1982.

55 En la región, entre los rasgos más característicos que dificultan la institucionalización y operatividad de los derechos con aplicación universal, destacan: 1) sobre concentración del poder (centralismo) político, económico, cultural y social (desdiferenciación social), 2) alianzas entre la burocracia mercantil y la oligarquía terrateniente (intereses comunes entre élites urbanas y rurales) y, 3) los efectos del corporativismo de Estado y del clientelismo político, que han articulado grupos y organizaciones que están bajo su subordinación (redes de exclusión-inclusión). 
del puro mercado a la tribalización que produce montoneras de individuos atomizados por los poderes fácticos y excluidos de sus derechos. ${ }^{56}$

Así, tanto las nuevas formas de sociabilidad, cuanto los movimientos sociales de protesta sociales, que vinieron a remplazar a al sujeto histórico en la región, han sido derrotados por las políticas de redemocratización y por la aplicación del modelo neoliberal en la economía o, por la primacía y disponibilidad de la ley tanto de instituciones espirituales, tecnológicas, comunicacionales, militares cuanto de las nuevas castas políticas que se han apoderado de los Estados y de los gobiernos. ${ }^{57}$

\section{LAS FUNCIONES DE LA CONSTITUCIÓN Y DEL ESTADO EN AMÉRICA LATINA}

Como se ha indicado, hoy en día nadie podría dudar que en América Latina se han desarrollado veloces procesos de modernización aun cuando la modernidad permanezca extraviada, precisamente porque los presupuestos de la diferenciación funcional, los cuales caracterizan a los sistemas sociales modernos, siguen siendo los grandes ausentes en la región: autorreferencialidad de los sistemas, clara separación entre sus códigos, construcción del futuro a partir de decisiones, institucionalización de las expectativas y disponibilidad de estructuras sociales (programas condicionales) para la operativización de la política, del derecho, etcétera. Dicho en otras palabras, reconocer que en las sociedades funcionalmente diferenciadas los sistemas parciales de la sociedad (derecho, política, religión, arte, economía, ciencia, etcétera), cumplen una función especial y única, lo cual además es el presupuesto para mantener la diferencia y la autopoiesis de estos subsistemas. Subsistemas sociales que en su lógica operativa son iguales (operan con base en un código), pero desiguales en cuanto a su función; y donde, por lo tanto, no existe primacía alguna ni tampoco un vértice exclusivo de coordinación..$^{58}$

56 Programa de las Naciones Unidas para el Desarrollo, La democracia en América Latina. Hacia una democracia de ciudadanas y ciudadanos, Informe 2004.

57 Sobre el congelamiento y debilitamiento de la sociedad civil en la transición chilena, véase Moulian, Tomás, Chile actual..., op. cit., nota 48.

58 Piénsese, por ejemplo, en situaciones de corrupción o colonización del sistema del derecho por la política. El caso de Chile, a la fecha sigue siendo paradigmático. Los candados constitucionales, como eufemísticamente se ha dado llamar a la estructura normativa que niega el Estado el derecho democrático, originalmente impuesta por Pinochet y 
Al respecto, uno de los problemas más acuciantes, si queremos definirlo así, reside en el hecho que es inmediatamente perceptible; la corrupción de los códigos de diferenciación, cuanto menos por la imposibilidad de localizar y de mantenerlos diferenciados de las innumerables influencias provenientes de la realidad social existente (redes de inclusión local, vías informales de representación y de composición de los conflictos, relaciones socioeconómicas que influencian la política y el derecho, relaciones clientelares, corrupción, caudillismo, etcétera), lo cual en términos prácticos dificulta la operatividad del derecho y del sistema político, impactando lógicamente sobre el sistema democrático y la ciudadanía.

Si observamos, por ejemplo, aquellos países en los cuales el sistema político se ha transformado en sentido "democrático" (Argentina, Brasil, Chile, Guatemala, México, Nicaragua, Uruguay, entre otros), podemos constatar que los problemas de indiferenciación social (en tanto sistemas) persisten, sorprendentemente adaptados, sin ulterior dificultad, a las exigencias políticas y jurídicas de la sociedad moderna, cuya apertura al campo constitucional viene depositada en una demiúrgica expectativa de confianza. Sin embargo, desde el punto de vista evolutivo sería simplista describir estos procesos desde la arquitectura explicativa de la residualidad social (tradición versus modernidad)..${ }^{59}$

sus adláteres, en la actualidad es reivindicada por el sistema político como el mecanismo más democrático, obliterando el hecho que en la práctica y debido al alto quórum requerido para aprobar las modificaciones a la Constitución y a las leyes "orgánicas" (sistema electoral binominal, Ley Orgánica Constitucional de Educación, Ley del Cobre), permite a un sector minoritario de la sociedad tanto una sobrerrepresentación en el Congreso Nacional, cuanto un poder absoluto en la toma de decisiones políticas (¿qué democracia?; cuando con sólo con un 33\% de la votación nacional este sector puede alcanzar cerca de la mitad de los asientos en el Congreso). Además, tras dieciséis años en el poder, los gobiernos de la Concertación de Partidos por la Democracia (Aylwin, Frei, Lagos, Bachelet) no sólo han aceptado el famoso "consenso democrático", sino que han hecho de este entuerto una verdadera ideología de estabilidad y gobernabilidad, lo cual sólo beneficia a una "inmensa minoría", toda vez que este consenso democrático se materializa en un cuoteo constante de cargos y asignaciones espurias (Corte Suprema, Televisión estatal, Banco Central, administración pública, etcétera), reactivando y profundizando, lógicamente, los mecanismos de corrupción, inclusión-exclusión a través del amiguismo, familiarismo y del clientelismo corporativo.

59 Capitalizando dicha confianza social, en Brasil, Ignacio Lula da Silva consolidó las políticas monetarias de F. Henrique Cardoso (las cuales antes había denunciado), 
Más bien debemos asumir que en América Latina la preocupación por el análisis y la reflexión en torno a la constitución del Estado y al modo en el cual éste habría debido organizarse ha estado ausente. Con esto no se desconoce que si bien es cierto que existen varias interpretaciones; sin embargo, no existe una autoobservación y autodescripción del Estado latinoamericano, es decir, una teoría del Estado latinoamericano que defina con claridad ¿qué cosa es el Estado en esta región? ${ }^{60}$ Tal vez ésta sea una de las razones por las cuales el Estado latinoamericano sea un Estado virtual, en el sentido que se constituye en la virtualidad del documento constitucional (texto), el cual ha tenido y tiene poquísimo que ver con la materialidad cultural y social (con el hecho, con el contexto). Quizás también por las mismas causas nuestros Estados periféricos acarrean problemas endémicos de soberanía interna y externa (Constituciones blindadas, soberanía bloqueada). ${ }^{61}$

amén de profundizar la corrupción como quedó de manifiesto luego que estallaron los escándalos en el PT tiempo atras; mientras en Argentina, Kirchner montado sobre la misma confianza se alía con los corruptos gorilas y peronistas antitrabajadores al tiempo que niega la personalidad jurídica a una de las pocas organizaciones con vocación democrática: la Central de Trabajadores Argentina. En Uruguay el electo presidente, Tabaré Vásquez parece hoy más preocupado por atraer inversiones extranjeras que de la dramática situación que golpea a los compesinos, y en Chile, consecuente con las reformas a la Constitución de 1980, el ex presidente Lagos realizó sus mejores esfuerzos a fin de amparar y generar un marco legal de "impunidad" para sus amigos y la casta política que en la toma de deciones públicas — sobre temas fundamentales de la ciudadanía - pudiese caer en prácticas de corrupción.

60 Precisamente, sobre estos aspectos giran las preocupaciones del último informe sobre la democracia en América Latina del PNUD 2004, La democracia en América Latina. Hacia una democracia de ciudadanas y ciudadanos..., op. cit., nota 56.

61 Ciertamente, los problemas contemporáneos de la ciudadanía social, del Estado democrático de derecho y de la democracia están estrechamente relacionados con las formas históricas de construcción del Estado-nación en América Latina y también con las formas de autorrepresentación y autodescripción que tales procesos han asumido (constituzionalización, efectividad y operatividad de la ley). Sobre estos problemas consultar los interesantes trabajos de Neves, Marcelo, A constitucionalização simbólica, Sao Paulo, Editoria Acedemica, 1994; Bolsan de Morais, J. Luis, Costituzione o barbarie, Lecce, Pensa Editore, 2004; Gomes Canotiho, J. Joaquin, Dalla constituzione dirigente al diritto comunitario dirigente, 2004; Autores Varios, Una costituzione da reinventare. Temi Brasiliani di critica costituzionale, Lecce, Pensa Editore, 2003. He desarrollado en extenso estas ideas en "Democracia y constitucionalismo en América Latina. El caso mexicano: entre el texto y el contexto" (en prensa). 
Al respecto, algunos autores han señalado que la formación del Estado y del constitucionalismo en América Latina habría sido una desviación del modelo ilustrado europeo (en este caso la teoría habría sido perfecta, pero es la realidad la que no cuadra: teoría de la desviación del ideal), mientras que para otros más cercanos a la realidad, el problema es que una minoría ilustrada se habría arrogado el derecho de construcción del Estado-nación y de la elaboración de la respectiva Constitución, que del mismo modo, luego resultaría extraña a la realidad (concepción autoritaria, clientelar y servil en función de las minorías criollas descendientes del colonialismo imperial).

Recordemos que el concepto clásico de Constitución moderna fue definido por Georg Jellenik en la segunda mitad del siglo XIX. Jellenik entiende la Constitución como el conjunto de principios jurídicos que definen los órganos supremos de un Estado; su creación y sus mutuas relaciones, las cuales determinan los ámbitos de su actuación y la situación de cada uno de ellos en relación con el poder del Estado. ${ }^{62}$ La Constitución es entonces un instrumento de gobierno, pues legitima procedimentalmente el poder, limitándolo; y, además, porque al crear el derecho, el Estado se obliga a sí mismo, y sometiéndose al derecho, se vuelve también sujeto de derechos y deberes.

Consecuentemente con este desarrollo, en términos generales, las funciones de la Constitución pueden ser sintetizadas básicamente en tres dimensiones: la democrática (formación de la unidad política), la liberal (coordinación y limitación del poder estatal) y la social (configuración social de las condiciones de vida). Todas estas funciones están integradas y se condicionan mutuamente. Por lo tanto, el significado de la Constitución no se agota en la regulación de los procedimientos de decisión, y de gobierno, y tampoco tiene por finalidad crear una integración social al margen de cualquier conflicto, muy por el contrario; ninguna de sus funciones pude ser entendida de forma absoluta o aislada. Por ello, la Constitución puede ser plenamente comprendida sólo en su totalidad.

62 Bercovici señala que el Estado es presupuesto por la Constitución, cuya función es regular los órganos estatales, su funcionamiento y esfera de acción, lo cual en consecuencia, también viene a delimitar la esfera de la libertad individual de los ciudadanos. Bercovici, Gilberto, "Constituçáo e política: uma relaçáo difícil”, Revista Lua Nova, Basil, núm. 61. 
Se debe tener presente también que la Constitución, en tanto instrumento formal de garantías, no tiene un contenido social o económico cualquiera, éste está determinado por una temporalidad histórica concreta y por el presupuesto de la soberanía del Estado constituyente, de ahí la importancia de la juridificación de la Constitución, como señala Kelsen. Si el Estado Constitucional es una conquista histórica, una lucha permanente frente a la ausencia de un Estado de derecho y de democracia, de ahí también la importancia que tiene una teoría de la Constitución, en tanto explicación realista del papel que juega en la dinámica política cotidiana. ${ }^{63}$

De cara a este problema, algunos órdenes constitucionales buscan racionalizar la política, incorporando una dimensión materialmente legitimadora, al establecer un fundamento constitucional para la política. En el fondo, dicha concepción está ligada fuertemente a la idea de que se puede cambiar la realidad a través del derecho. Es decir, cambiar la realidad a partir de la Constitución, toda vez que se piensa en una teoría constitucional tan poderosa que la Constitución por sí misma sería capaz de resolver todos los problemas de la sociedad (instrumentalismo constitucional: querer cambiar la sociedad, transformar la realidad, apenas con los mecanismos constitucionales: la ley por la ley). ${ }^{64}$

Entonces, más allá del instrumentalismo constitucional, el problema no radica tanto en la legitimación cuanto en las permanentes tendencias de deconstitucionalización de la Constitución; deconstitucionalización que favorece la mantención de los privilegios y desigualdades. Lógicamente, esto significa en términos prácticos la reducción de la ciudadanía, ya que - como señala Marcelo Neves_- la no concretización de la Constitución (operatividad, efectividad) cierra espacios para el ciudadano y también para la vivencia democrática. Y esto precisamente a causa

63 Leowenstein, Karl, Teoría de la constitución, Barcelona, Ariel, 1976, pp. $217-$ 222; véase además, Heller, Herman, Teoría del Estado, México, Fondo de Cultura Económica, 1997.

64 Por ejemplo, en el núcleo de la idea de la Constitución dirigente está la propuesta de legitimación material de la Constitución a través de los fines y tareas previstos en el texto constitucional; lo que para Canotilihio significa que el problema de la Constitución dirigente es un problema de legitimación. Canotilhio, José Joaquín, Direito constitucional, Almedina, Coimbra, 1993; constituçáo dirigente e vinculaçáo do legislador: contributo para a compreensáo das normas constitucionais programática, Portugal, Coimbra, 2001, pp. 13 y 14, 27-30, 42-49, 462, passim. 
de la ausencia generalizada de vínculos sociales (constitución simbólica). Ausencia, insuficiencia o fragilidad institucional de los textos constitucionales en la región ha sido usada en modo retórico para legitimar a los gobernantes, los gobiernos y los grupos en el poder.

Al respecto, Neves traza una teoría de la deconstitucionalización factual, es decir de un cambio puramente político, ya que surge un nuevo texto legal (pero) sin un vínculo consistente con la normativa que emana de los textos constitucionales precedentes y, sobre todo, sin algún sostén en los procedimientos legales prestablecidos. Así, de un lado el derecho en la Constitución es bloqueado por diversos factores sociales (clientelismo, corporativismo, corrupción), criterios y códigos de preferencia que le impiden cumplir firmemente la función de filtro frente a otras influencias del entorno sobre el sistema legal. De otro lado, la relación autodestructiva y heterodestructiva entre política y derecho implica una implosión de la Constitución como acoplamiento estructural entre ambos sistemas, a cargo especialmente de la autonomía del derecho. De tal forma que la influencia de la política sobre el derecho no es en muchos aspectos ni en modo relevante filtrada por los procedimientos constitucionales de un Estado de derecho.

En este sentido, para Neves el derecho latinoamericano no sería autopoiético sino más bien alopoiético en relación con la política. Esto porque sus decisiones respecto de lo legal/ilegal, son producidas generalmente por la política siendo una práctica política permanente en América Latina, no son tematizadas en la contingencia del sistema legal precedente como sería indispensable para la reflexividad de un sistema de derecho con altos niveles de autonomía (irritación/motivación). Lo que sucede en la práctica es que se convoca a una asamblea constituyente especial para cambiar la totalidad del orden legal, pero no cambia nada. ${ }^{65}$

Por esto Neves señala que el problema sistémico de la región no tiene nada que ver con una carencia de apertura cognitiva (heterorreferencia), sino con la insuficiente clausura operativa (autorreferencia), que impide la construcción de la identidad del sistema legal. Lo cual se explica porque sistemas funcionales específicos, cuya autonomía no ha sido comple-

65 Para la hegemónica "ciencia política", tan en boga, mientras más cuantificables, medibles y alturables sean estas dimensiones/indicadores, más certeza se gana en cuanto al problema de la política democrática. Pero tal perspectiva, más que poblematizar el problema de la convivencia democrática, la tecnifica. 
tamente desarrollada, hacen difícil su inmunización contra las intervenciones externas de la política, generando problemas de diferenciación y haciendo perder al sistema del derecho la capacidad de asegurar las expectativas normativas de la sociedad.

La observación que realiza Neves está claramente ejemplificada cuando se estudia la discusión sobre el Estado latinoamericano en las últimas décadas. Aquí se hace evidente la construcción de una concepción técnica-formal que quiere explicar la operación prociedimental de un conjunto de burocracias que aparecen ocultas y extrañas a la sociedad. En estas elaboraciones, el Estado viene concebido como un conjunto de estructuras y procedimientos que necesitan salvaguardarse para no comprometerla "gobernabilidad democrática", de modo que dichas conceptualizaciones terminan en general por poner el acento sobre el régimen político, los sistemas de partido, el conteo de los votos y las elecciones en modo descontextualizado e irreflexivo, tal que parecen responder más a intereses políticos ideológicos que al estudio del problema de las estructuras sociales disponibles (cognitivas y normativas) para los ciudadanos en el Estado democrático de derecho. ${ }^{66}$

\section{USOS Y ABUSOS DE LA DEMOCRACIA: ¿CONCLUSIONES?}

Cinismo, un sinónimo de político Julio César

En el proceso evolutivo de la modernidad en el continente latinoamericano, los recursos de los sistemas funcionales de la sociedad vienen opacados por el sistema político; situación que en parte explica la actual desintegración y apatía social, la violencia y la debilidad del Estado y del

66 Es importante tener presente que cuando se estudia el Estado se deben especificar, distinguir, considerar y relacionar analíticamente cuatro dimensiones fundamentales: 1) el Estado como burocracia que realiza acciones en vista de un bien público (eficacia); 2) el Estado como sistema legal que organiza y penetra las relaciones sociales (legalidad efectiva que potencia la sociedad ofreciendo aceptables grados de seguridad y certeza.; 3) el Estado (toda forma de autoridad legítima, excepto - claro - una dictadura), que existe para los otros: base discursiva sobre la cual históricamente se funda el Estado-nación (dimensión de credibilidad: bien público), y 4) el Estado como intermediario entre las relaciones sociales en vista de un bien público (como ambición de filtro eficaz: orden social). 
sistema de derecho. Signado por recursivas y crecientes crisis de funcionalidad de los subsistemas sociales, y la consecuente (i)legitimidad de las instituciones, se genera una situación que constituye el caldo de cultivo en donde se incuban las múltiples formas de indiferenciación social, política, económica y jurídica existente en la región. ${ }^{67}$

Empero, si se acepta, por ejemplo, que la calidad de la democracia en la región es el reflejo del triunfo de la "democracia procedimental" ( $a d$ ministrada por las nuevas oligarquías en el poder), resulta interesante interrogarse si el déficit de la democracia electoral en la región es realmente un déficit o la forma lógica en la cual se articulan este género de democracias, sobre todo si se piensa que - de un tiempo a esta parte - el acento analítico viene puesto, en general, sobre el problema técnico de la "gobernabilidad democrática", cuya preocupación por la estabilidad (gobernabilidad) resulta siempre más importante que la preocupación por la democracia misma. ${ }^{68}$

67 Para el caso de México, señala Lorenzo Meyer (Primer Plano, 17 de octubre de 2005) que: "hay un hartazgo de presente pero no existen vínculos (expectativas) con el futuro (como ocurría en la década de los cuarenta y cincuenta, con el 'desarrollo estabilizador' en México, incluso quizás hasta el gobierno de M. Echeverría)... En México falla el proyecto de modernización y modernidad, pero ya no como debilidad gubernamental, sino como debilidad de las expectativas (desesperanza). No existe proyecto de Estado ni sentido de país. ¿Dónde y cuál es el proyecto de país? Entonces, es un fracaso porque no hay consenso amplio, sino un eterno presente (gestión y política reactiva). Hay demagogia y populismo pero no hambre de futuro... Por ejemplo, el voto corporativo que existe en México, cuya expresión mas dramática está dada por el poder que ejerce la dirigente magisterial Ester Gordillo (ex PRI), quien controla el mayor sindicato de profesores de América Latina".

68 En este sentido, estamos de acuerdo con Pablo González Casanova cuando señala que por "gobernanza" se entiende el arte de construir Estados, gobiernos y elecciones funcionales al Estado trasnacional emergente, el cual integra a los complejos empresariales-militares que lo crean para asegurar su dominación y acumulación. La "gobernanza" se hace efectiva con "estrategias de largo alcance" que se aplican entre luchas, enfrentamientos y negociaciones, escogiendo con un sentido práctico las medidas que se toman en un momento y lugar dados para alcanzar los objetivos de sus "valores e intereses" en forma inmediata, o en varias etapas, cuando sea necesario ("México: ésta no es democracia", Rebelión, 13 de julio de 2006). Recordemos que según las tesis huntingtonianas, la ingobernabilidad es la pérdida de control estatal generada por la sobrecarga de la demanda cuidadana (inclusión). Al respecto, en el caso del proceso de democratización en Chile al parecer es, precisamente, el tema de la estabilidad económica - lex mercatoraquello que viene a definir la "democracia". 
Resulta evidente, como se ha indicado, que desde el punto de vista histórico-evolutivo, los sistemas político-democráticos en la periferia de la sociedad moderna han alcanzado un grado de diferenciación como sistemas de control social centralizado, que engloban de manera creciente "la ciudadanía" en la organización política. Sin embargo, paradójicamente tal inclusión ha generado al mismo tiempo exclusión, sobre todo a causa de la persistencia de formas - también históricas - de sobrexposición de las prácticas políticas a la supremacía eterárquica de relaciones clientelares, sustitutivas o alternativas a la operatividad jurídica de los procedimientos constitucionales; obstaculizando el despliegue de las estructuras sociales disponibles para profundizar, estabilizar y operativizar la democracia en pos de "ampliar" la ciudadanía. ${ }^{69}$

Es dable entonces plantear, en vía de hipótesis, que el bajo nivel de institucionalización democrática en el continente latinoamericano está directamente relacionado con la fragilidad congénita de la civilización de las expectativas cognitivas de la sociedad y con la constante ausencia operativa del derecho y del constitucionalismo, en tanto prácticas normativas de diferenciación funcional.

Aceptando esta premisa hipotética, resulta lógico pensar entonces que cualquier tipo de "ciudadanía" tiene necesidad de certezas jurídicas básicas en tanto un bien público universal (confianza, que no es lo mismo que la leguleyada de la ley por la ley). Certeza jurídica, como bien público universal que en todo orden democrático proviene de la convicción generalizada de que existe un curso normal y previsible de los hechos, y cuando éstos lleguen a ser controvertidos, es plausible recurrir y confiar en la decisión de los tribunales, toda vez que la ley no tiene otro objetivo que la operativización de las decisiones vinculantes sobre la base del respeto a sus fundamentos, incluso cuando las decisiones del legislativo puedan ser drásticas o difíciles.

Más aún, si como he señalado en otro lugar, en América Latina no existe una teoría del Estado que defina con claridad qué cosa sea el Estado, es indispensable adoptar una prospectiva más amplia para afrontar el

69 También sin problematizar todavía cuáles y dónde están estas estructuras sociales disponibles. Sin profundizar tampoco sobre los problemas como aquellos de la conceptualización de estos fenómenos. Hoy existe una alarmante imprecisión conceptual, se habla de gobiernos democráticos, de transiciones democráticas, etcétera, pero no es claro de qué cosa se está hablando. 
problema del "déficit de la "democracia" y la fragilidad del Estado, para responder a los problemas del por qué, para qué, cuál es el sentido de la democracia, qué tipo de Estado, qué cosa es el Estado y cuánto de Estado queda actualmente en la región; y por cierto definir y problematizar el necesario vínculo entre las expectativas cognitivas (culturales) y la democracia, ya que si afirmamos que la democracia es un proceso de construcción normativa y de producción social, entonces el proceso democrático está necesariamente vinculado a la cultura, es decir, a las expectativas cognitivas de la sociedad y también a las formas y recursos disponibles para institucionalizar tales expectativas (norma). ${ }^{70}$

Pero, en realidad en América Latina históricamente la cultura ha tenido una impronta de carácter patrimonial, la cual no ha sido modificada por las formas democráticas, precisamente porque ha existido una tensión constante entre el modelo identitario (exclusivo y excluyente) y el modelo de modernidad (incluyente y abierto) lo cual, en definitiva, ha estado a la base de las frecuentes crisis sociopolíticas. ${ }^{71}$ Específicamente, es a esto a lo que se refiere O'Donnell cuando habla de las zonas marrones, como aquellos lugares en los cuales el Estado se orienta a través de modelos clientelares y en ocasiones por lógicas relacionales cuasi feudales, caracterizadas por un marcado distanciamiento de los regímenes políticos y de los grupos que se han apoderado del aparato estatal y por las regiones liminares entre democracia y autoritarismo (ruptura y desarticulación de las estructuras sociales y políticas de los Estados, de las instituciones democráticas, subciudadanización de la ciudadanía, revitalización del clientelismo populista y politización de la desigualdad).

Es sobre este trasfondo que el procesualismo de la democracia electoral ha acordado un pacto de miedo (como impotencia del deber ser), que lo único que promete es la estabilidad para digerir el trauma de una crisis en la cual se ha perdido toda inocencia. Tal que en este esquema los valores de la democracia residen no en su positividad sino en las consecuencias negativas de la ausencia de democracia. De una democracia re-

70 Recordemos que para K. Schmitt, el derecho constitucional es siempre la cultura puesta por escrito (de ahí su apelo a la defensa de la Constitución).

71 Por mucho tiempo - ilusoriamente - se ha pensado que con "la imposición" de la democracia procedimental o con las así llamadas "transiciones democráticas", estas prácticas sarían cambiadas. El problema evidente es que el procedimentalismo impuesto no puede modificar modelos culturales, es sólo la vivencia democrática cotidiana la que puede generar procesos y órdenes sociales democráticos. 
gulada, y no de una democracia como verdadera competencia entre diversas finalidades - también si éstas son opuestas-; democracia en la cual el orden y sus cristalizaciones de poder económico-cultural, de poder meta-político, por así decir, están calculadas, establecidas y garantizadas por/para un minoritario y selecto grupo.

No es exagerado entonces sostener que en América Latina la (con)vivencia sociopolítica es esquizofrénica y altamente polarizada, toda vez que aquí coexisten Estados de derecho sin derecho, ciudadanos sin ciudadanía efectiva, crecimiento económico pero sin "desarrollo" y democracias formales pero sin democracia real. Y la cosa peor de este affaire es que realidades así dramáticas se reifican (devienen casi naturales) y pasan a formar parte del paisaje cotidiano. Baste observar que tanto los políticos de izquierda cuanto de derecha y los burócratas que toman las decisiones públicas sobre temas fundamentales de la ciudadanía y el sistema "democrático", raramente se ven afectados o atacados por éstas.

Porque aun cuando escándalosa, esta situación se refleja indudablemente en el reciente informe sobre La democracia en América Latina del PNUD 2004, donde se constata y observa cómo se han reactivado las relaciones clientelares y serviles, mientras se va concentrando el poder no solamente en los grupos económicos sino también en aquellos grupos políticos, los cuales han estipulado un recíproco pacto de protección e impunidad, propiciando indiferenciación operativa en pos de los propios intereses y anulando la efectividad del Estado, el derecho y el sistema político.

\section{BIBLIOGRAFÍA}

AUTORES VARIOS, Una costituzione da reinventare. Temi brasiliani di critica costituzionale, Lecce, Pensa Editore, 2003.

ALBERTI, Giorgio, La construcción de la democracia en América Latina, México, FLACSO, 1997.

BERCOVICI, Gilberto, "Constituçáo e política: uma relaçáo difícil”, Revista Lua Nova, Brasil, núm. 61 (fotocopia).

BOAVENTURA DE SOUSA, Santos, Nuestra América reinventando un paradigma subalterno de reconocimiento y redistribución (fotocopia). 
, "O estado e o dereito na transiçâo pós-moderna: para um novo senso comun sobre o poder e o dereito", Revista Crítica de Ciências Sociais Brasil, núm. 30, 1990.

BoBBIO, Norberto, Il futuro della democrazia. Una difesa delle regole del gioco, Torino, Einaudi-Nuovo Politecnico, 1984.

\section{— L'età dei deritti, Italia, Einauidi Editore, 1990.}

BOLSAN DE MORAIS, J. Luis, Costituzione o barbarie, Lecce, Pensa Editore, 2004.

BRUNNER, José J., Un espejo trizado, Santiago, FLACSO, 1988.

CANOTILHIO, José Joaquín, Constituçáo dirigente e vinculaçáo do legislador: Contributo para a compreensáo das normas Constitucionais programática, Portugal, Coimbra, 2001.

, Dalla constituzione dirigente al diritto comunitario dirigente, Lecce, Pensa Editore, 2004.

, Direito constitucional, Almedina, Coimbra, 1993.

CAStro-Gómez, SAntiago, Eduardo Mendieta, Teorías sin disciplina. Latinoamericanismo, poscolonialismo y globalización en debate, México, USF-Porrúa, 1998.

COHEN, Jean y ARATO, Andrew, Sociedad civil y teoría politica, México, Fondo de Cultura Económica, 2000.

CORSI, Giancarlo, "Valores y derechos fundamentales en perspectiva sociológica”, Revista Metapolítica, México, núm. 20, 2001.

Sistemi che apprendono, Lecce, Pensa Multimedia, 1998.

DAHL, Robert, La democracia y sus críticos, Barcelona, Ediciones Paidós, 1993. 1993.

La poliarquía. Participación y oposición, México, REI Editores, - Un prefacio a la teoría democrática, México, Ediciones Gernika, 1987.

DeleuZE, Gilles, En medio de Spinoza, Buenos Aires, Cactus, 2005.

DIAMOND, Larry y PLATTNER, Marc F. (comps.), El resurgimiento global de la democracia, México, UNAM-IIS, 1997.

ELÍAS, Norbert, El proceso de la civilización. Investigaciones sociogenéticas y psicogenéticas, México, Fondo de Cultura Económica, 1994.

HÄBERLE, Peter, Constitución como cultura, Bogotá, Instituto de Estudios Constitucionales Carlos Restrepo Piedrahita, 2002.

HABERMAS, Jürgen, Facticidad y validez, Madrid, Taurus, 1998. 
, Fatti e norme. Contributi a una teoria discorsiva del diritto e della democrazia, Milán, Guerini Editore, 1992.

Huntington, Samuel P., El orden politico en las sociedades en cambio, Barcelona, Paidós, 1996.

— L L L tercera ola. La democratización a finales del siglo XX, Barcelona, Paidós Editorial, 1996.

HeLler, Herman, Teoría del Estado, México, Fondo de Cultura Económica, 1997.

KANT, Emmanuel, Filosofía de la historia, México, Fondo de Cultura Económica, 1979.

KELSEN, Hans, Lineamenti di dottrina pura del diritto, Turín, Biblioteca Einaudi, 1952.

— Socilogia della democrazia (a cura di Agostino Carrino), Nápoles, Edizioni Scientifiche Italiane, 1991.

LECHNER, Norbert, "Sociedad civil: revisión crítica de un concepto", en RinCón Gallardo, G. (coord.), Partidos politicos y sociedad civil, México, Centro de Estudios sobre la Reforma del Estado, 1995.

LECHNER, Norbert, "La (problemática) invocación de la sociedad civil", Revista Perfiles Latinoamericanos, México, año 3, núm. 5, 1994.

LEOWENSTEIN, Karl, Teoría de la Constitución, Barcelona, Ariel, 1976.

LUHMANN, Niklas, "Causalità nel Sud", en CORSI, Giancarlo y GIORGI Raffaele de, Ridescrivere la questione meridionale, Lecce, Pensa Editore, 1998.

- Introducción a la teoría de sistemas, México, Lecciones publicadas por Javier Torres Nafarrate, Anthropos Editorial-Universidad Iberoamericana, ITESO, 1996.

— L L L differenziazione del diritto, Italia, Il Mulino, 1990.

— L L L política de la sociedad, Alemania, traducción provisoria de Javier Torres Nafarrate, 2001.

— Organización y decisión. Autopoiésis, acción y entendimiento comunicativo, Barcelona, Anthropos Editorial, 1997.

—, Orgnizzazione e decisione, Milán, Bruno Mondadori, 2005.

—_ Sistemas sociales. Lineamientos para una teoría general, México, Alianza Editorial-Universidad Iberoamericana, 1991.

LYOTARD, Jean F., "Qué era la postmodernidad", en CASULLO, Nicolás, El debate modernidad. La modernidad, Buenos Aires, Punto Sur, 1989.

— La condición postmoderna, Madrid, Ediciones Cátedra, 1989.

MARCH, J., H. Simon, Teoría de la organización, Barcelona, Ariel, 1981. 
Marshall, Thomas H., Class, Citizenship and Social Development, Doubleday and Company, 1965.

y BOTTOMORE, Tom, Ciudadanía y clase social, Madrid, Alianza Editorial, 1998.

MASCAREÑO, Aldo, "Teoría de sistemas de América Latina. Conceptos fundamentales para la descripción de una diferenciación funcional concéntrica", Persona y Sociedad, vol. XVII, núm. 2, 2003.

MAYNTZ, Renate, Sociologia dell' amministrazione pubblica, Italia, Il Mulino, 1982.

Mires, Fernando, Ciencia Nueva (título provisorio del manuscrito), Alemania, Odenburg, 2002.

Moulian, Tomás, Chile actual. Anatomía de un mito, Santiago, LOM Ediciones, 1997.

NeVES, Marcelo, A constitucionalização simbólica, São Paulo, Editora Académica, 1994.

O’DONNELL, Guillermo, “Delegative Democracy”, Journal of Democracy, núm. 5, 1997.

, "Estado y Alianzas en la Argentina, 1956-76", Desarrollo Económico, núm. 64, Argentina, vol. 16, 1977.

PROGRAMA DE LAS NACIONES UNIDAS PARA EL DESARROLlO, La democracia en América Latina. Hacia una democracia de ciudadanas y ciudadanos, Informe 2004.

RANCIÈRE, Jacques, Aux bords du politique, París, Osiris, 1990.

SCHMITT, Karl, Teoría de la Constitución, Madrid, Alianza Universidad, 1982.

STEINER, George, En el Castillo de Barba Azul. Aproximación a un nuevo concepto de cultura, Barcelona, Gedisa, 1992.

SCHUMPETER, Josep, Capitalismo, socialismo e democrazia, Milán, Etas Libri, 1977.

ZAMORANO FARÍAS, Raúl, Civilizzazione della aspettative e democrazia nella periferia della società moderna, Lecce, Biblioteca Pensa Multimedia, 2004.

—, Entre la teoría y la acción. Dilemas sobre la acción colectiva popular Santiago de Chile: 1988-1992, México, Juan Pablos Editor, 2001. , "Formas históricas de coordinación social en América Latina: de la teoría de la dependencia al fetichismo neoliberal", Rivista Teoria del Diritto e dello Stato, Turín, Aragne Editore, 2006 (en prensa). 